Per Ledin, Catharina Nyström Höög, Johan Tønnesson och Gustav Westberg

\title{
Den multimodala sakprosan
}

\section{The Multi-modal Non-fiction ('sakprosa')}

Tidsskriftet Sakprosa

Bind 11, Nummer 4

(C) 2019

10.5617/sakprosa.7072

Ledin, Nyström Höög, Tønnesson och Westberg 


\section{Sammandrag}

Alla sakprosatexter är multimodala, och denna artikel diskuterar relationen mellan sakprosaforskning och multimodalitetsforskning. Artikeln adresserar två frågor: Hur kan forskning om multimodalitet och sakprosa stimulera varandra? och Hur förhåller sig nordisk sakprosaforskning till en vidare multimodal forskningstradition? För att besvara dessa frågor tecknar artikeln multimodalitetstraditionens utveckling samt härleder sakprosabegreppets ursprung. I ljuset av såväl äldre som nutida sakprosaforskning argumenterar artikeln för att sakprosabegreppets multimodala potential huvudsakligen ligger i förledet sak eftersom det riktar ljuset mot textens roll som ett yttrande om verkligheten inom en institution. Således argumenterar artikeln att samspelet mellan verbalspråket och andra semiotiska resurser bör stå i centrum vid studiet av sakprosa, oberoende av om det handlar om ett samspel mellan verbalspråk och t.ex. visuella, rumsliga eller auditiva resurser. Detta pekar slutligen på nödvändigheten i att uppmärksamma hur olika affordanser - dvs. möjligheter och begränsningar - i olika semiotiska material används i olika kontexter. Därmed blir också efterledet prosa relevant, eftersom de riktar uppmärksamheten mot kvaliteter $i$ uttrycket.

\section{Abstract}

All non-fictional prose ('sakprosa' in the Scandinavian languages) is multimodal, and this paper discusses how the study of non-fictional prose relates to research on multimodality. In doing so, the paper answers two research questions: How can research on non-fictional prose and multimodality enrich each other? and How does Nordic research on nonfictional prose relate to the wider field of multimodality? In order to answer these questions, the trajectories of the multimodality tradition are outlined as well as the genealogy of the concept sakprosa. Drawing on older as well 
as contemporary Nordic research on non-fictional prose, the article argues that the prefix sak has at its potential to inform multimodality research, primarily because it conceptualizes text as an utterance about the reality within a specific institution. Accordingly, the article argues that the interplay between language and other semiotic (e.g. visual; spatial; auditive) modes needs to be fore fronted in the study of non-fictional prose. This, finally, points to the importance of paying attention to how different affordances, i.e. the possibilities and constraints in different semiotic materials, are employed in different contexts. Thus, the suffix prose also becomes relevant, as it draws attention to the qualities of the expression.

Nyckelord: multimodalitet; sakprosa; affordans; visuell analys; semiotik; socialsemiotikk, systemisk-funktionell lingvistik; värdegrundstexter; flygplatsanalys

Keywords: multimodality; 'sakprosa'; non-fiction; affordance; visual analysis; semiotics; social semiotics; systemic-functional linguistics (SFL); platforms of values; airport analysis

\section{Om författarna:}

Per Ledin är professor i svenska språket vid Södertörns högskola. per.ledin@sh.se

Catharina Nyström Höög är professor i svenska språket vid Högskolan i Dalarna och vid Uppsala universitet. cnh@du.se

Johan Tønnesson är professor i sakprosa ved Universitetet i Oslo. johan.tonnesson@iln.uio.no

Gustav Westberg är biträdande lektor i svenska språket vid Örebro universitet.gustav.westberg@oru.se 


\section{Den multimodala sakprosan}

\section{Inledning ${ }^{1}$}

Texter har aldrig varit fullt ut monomodala. Runskriftens tecken präglas av stenhuggarens teknik precis som handskriften präglas av skrivaren och dennes handstil och den tryckta skriften undslipper aldrig typografin (Bolter 2001, Tønnesson, 2006). Inte heller talspråket kan verka utan stämma och röstkvalitet hos talaren. Verbalspråket kommer alltså sällan ensamt. Detta har arkeologer, teologer, historiker och filologer alltid vetat; det är sedan gammalt. Men parallellt med att it-revolutionen för ett tiotal år sedan också blev en visuell och multimodal revolution, uppstod ett förnyat forskningsintresse för verbalspråkets samspel med andra semiotiska resurser. Det innebar en insikt om att sakprosan alltid varit multimodal och om att det finns yttranden och texter som skapar betydelse helt utan verbalspråk. Ingen som idag bedriver text- och sakprosaforskning kan helt bortse från insikterna från den idag rika forskning som utvecklat vår förståelse för att texter kommunicerar på många sätt (Løvland, 2007), dvs multimodalt.

I den här artikeln försöker vi besvara följande två frågor: Hur kan forskning om multimodalitet och sakprosa stimulera varandra? och Hur förhåller sig nordisk sakprosaforskning till en vidare multimodal forskningstradition? För att besvara dessa frågor presenterar vi i nästföljande avsnitt en teoretisk genomgång av multimodalitetstraditionen, där vi gör en åtskillnad mellan socialsemiotik och systemisk-funktionell lingvistik som delvis olika forskningstraditioner. Med denna redogörelse som bakgrund diskuterar vi därefter sakprosabegreppets ursprung, och med avstamp i såväl äldre som

\footnotetext{
${ }^{1}$ Författarna vill tacka Christina Matthiesen för viktiga bidrag till denna artikel.
}

Ledin, Nyström Höög, Tønnesson och Westberg 
nyare studier, resonerar vi om begreppets potential för multimodal textforskning. Avslutningsvis pekar vi framåt genom att föreslå möjliga vägar för kommande multimodal sakprosaforskning.

Vi som författat artikeln hör hemma i Norge och Sverige, där också (multimodal) sakprosaforskning pågått i decennier. Detta gör att framställningen har en tyngdpunkt på forskning från dessa två länder, även om mycket annan forskning, inte minst dansk, också behandlas.

\section{Teoretisk bakgrund}

Multimodalitet har sedan millennieskiftet blivit ett viktigt begrepp inte minst för språkvetare som vill komma åt det faktum att språk med nödvändighet artikuleras tillsammans med andra modaliteter. Så sker i tal, där blickar, kroppshållning och beröring är en del av en multimodal interaktion (t.ex. Norris, 2004), och i skrift, där typografi, layout, bilder och illustrationer är en självklar del av meningsskapandet (t.ex. Kress \& van Leeuwen, 1996). Går vi till ett nutida översiktsverk som Jewitt, Bezemer och O’Halloran (2016) märker vi att distinkta forskningsinriktningar urskiljs, varav de huvudsakliga utgår från systemisk-funktionell lingvistik (SFL), socialsemiotik (SS) och samtalsanalys (CA). Till detta kan läggas kritiskt inriktade diskursanalyser av multimodala texter (t.ex. Multimodal Critical Discourse Analysis, MCDA, Ledin \& Machin, 2018a) och spatiala diskursanalyser (SDA, Ravelli \& McMurtrie, 2016). Inte minst i Norden har också visuell retorik blivit en forskningsinriktning (t.ex. Kjeldsen, 2002). Vi ser alltså att olika sorters multimodalitetsanalyser kan urskiljas, ofta med den sortens akronymer som typiskt används för att lansera sådan forskning som gör anspråk på att vara ett eget fält. 
Denna artikel beskriver inte dessa olika inriktningar i detalj, utan fokus ligger på att redogöra för hur nordisk sakprosaforskning på olika sätt hämtat näring ur olika slags multimodalitetsforskning. De traditioner som då blir viktigast är socialsemiotiken och den forskning som vuxit fram ur den systemiskfunktionella lingvistiken. Vi går här igenom hur dessa inriktningar tagit form och pekar på teoretiska distinktioner som är viktiga för dagens multimodalitetsforskning.

\section{Socialsemiotik}

Allmänt kan sägas att den multimodala sakprosaforskningen har sin bakgrund i den semiotik som vuxit fram i den europeiska strukturalismen. Redan Saussure (1970/1914) talade om semiologi och pekade på tecken som godtyckliga kombinationer av uttryck och innehåll (signifiant och signifié), och behandlade vidare tecknens associativa relationer (eller paradigmatiska relationer som Hjelmslev (1943) sedan uttryckte det) och syntagmatiska artikulering (hur enheter från paradigm kombineras).

Denna idé är fortfarande viktig. Exempelvis Barthes (1967) visar på hur tecken måste förstås både som paradigm och syntagm (se nedan), och Malmbergs (1973) för sin tid nydanande semiotikbok heter typiskt nog Teckenlära. Malmberg verkade för övrigt vid Lunds universitet, där avdelningen för Kognitiv semiotik i dag finns och där NASS, Nordic Association for Semiotic Studies, grundad 1987, har sitt säte. I denna miljö finns en inriktning på bildens semiotik (Sonesson, 2011). Barthes är en viktig inspiration här, liksom allmänt i socialsemiotiken. Men också amerikanen Peirces (1931) teckenlära har haft stort genomslag inom såväl allmän- som socialsemiotik. Peirce skilde på tre teckentyper - ikoniska, indexikala och symboliska- för att klargöra den semiotiska grunden för relationen mellan uttryck och innehåll. Förenklat är den semiotiska grunden hos dessa tre teckentyper i tur och 
ordning likhet, närhet och symbolik (jfr Sonesson, 2011:123ff.). Peirce upprättar typologier utifrån dessa teckentyper och betonar att de kan kombineras och har inslag av varandra.

Med stöd i Barthes visar en nordisk lärobok i marknadskommunikation (Frandsen, Johansen \& Nielsen, 1997) hur kläder kan förstås som en särskild kod. Vi väljer olika typer av kläder paradigmatiskt (för överkropp, underkropp etc.) och kombinerar typerna syntagmatiskt (så att en viss skjorta eller blus kombineras med vissa byxor eller kjolar i enlighet med gällande konventioner). I systemisk-funktionell lingvistik, som vi snart kommer tillbaka till, betonas det paradigmatiska starkt, vilket rent praktiskt innebär att ett system, eller en grammatik, ses som en uppsättning val inom ett paradigm.

Beteckningen socialsemiotik kom att få fäste när Hodge och Kress (1988) publicerade boken Social Semiotics (jfr Bezemer \& Jewitt, 2009). Boken inleds med att författarna tar sig an semiotiska nyckeltänkare, främst Saussure, och argumenterar för att den semiotiska beskrivningen också måste vara social och ta in kontexter. I sin argumentation hänvisar de även till Voloshinov (1986/1929), som var samtida med Bakhtin och argumenterade för att tecken måste ses som en del av den sociala och materiella verkligheten. Hodge och Kress (1988) menar att den traditionella semiotiken "likes to assume that the relevant meanings are frozen and fixed in the text itself", alltså att det finns en given kod, och att ett socialsemiotiskt perspektiv på betydelse i kontext innebär ett fokus på "the struggles and their uncertain outcomes that must be studied at the level of social action, and their effects in the production of meaning" (s. 12 ).

Med den infallsvinkeln blir inte heller tecken, som hos Saussure, arbiträra. Denna syn är återkommande hos Kress, som talar om the motivated sign och 
menar att "signs are made - not used - by a sign-maker who brings meaning into an apt conjunction with a form, a selection/choice shaped by the signmaker's interest” (2010:62). Det kan noteras att Hodge och Kress (1988) influerade starten av tidskriften Social Semiotics 1991, som har ett fokus på hur semiotiska praktiker och resurser "are connected to the organization of societies and everyday lives". ${ }^{2}$

Den socialsemiotiska vändningen innebar också, vilket är viktigt för sakprosaforskningen, att populärkulturella texter sattes på dagordningen. Hodge och Kress (1988) tar sig an sådant som dagstidningar, reklamaffischer, familjefoton och serietidningar, alltså sådant som omger oss i samhället och som påverkar vad vi gör och tänker (jfr Seiler Brylla, Westberg \& Wojahn, 2018 för liknande iakttagelser kopplat till den kritiska lingvistikens framväxt). Traditionellt hade mycket humanistisk vetenskap, språkvetenskapen inkluderad, mer intresserat sig för kulturellt högt värderade texter, som den konst och litteratur som en viss kultur tillmäter ett särskilt estetiskt värde.

Under 1990-talet kom efterhand termen multimodalitet att användas alltmer inom det socialsemiotiska perspektivet, och med Kress och van Leeuwens bok Multimodal Discourse (2001) började termen bli allmänt vedertagen (jfr Ledin \& Machin, 2018b: kap. 2). Kress och van Leeuwen (2001) säger att semiotiska resurser eller modaliteter har tenderat att beskrivas var för sig, men att meningsskapande alltid är multimodalt, där multimodalitet förstås som "[t]he use in several semiotic modes in the design of a semiotic product or event" (s. 20). Detta ses mot bakgrund av att den digitala utvecklingen gett

\footnotetext{
2Aims and scope: https://www.tandfonline.com/action/journalInformation?show=aimsScope\&journalCode=cs $\underline{\text { os20 }}$
}

Ledin, Nyström Höög, Tønnesson och Westberg

Sakprosa.no 
upphov till nya sätt att designa texter eller semiotiska artefakter, också för vanliga människor, eftersom nya teknologier blivit masspridda. Att termen idag är etablerad märks bl.a. på att Routledge förlag gett ut en Handbook of Multimodal Analysis 2014 (Jewitt, 2014) och på den internationella konferensen International Conference on Multimodality som anordnas vartannat år. Den nionde i ordningen arrangerades i Odense 2018, vilket inte är en tillfällighet. Vid Syddansk Universitet finns en stark multimodal forskningsmiljö, där van Leeuwen under 2010-talet varit professor och bidragit till miljöns socialsemiotiska och systemisk-funktionella inriktning.

\section{Systemisk-funktionell lingvistik}

Det finns ingen skarp gräns mellan socialsemiotiken och den multimodalitetsforskning som bygger på systemisk-funktionell lingvistik (jfr O’Halloran, 2008; Bezemer \& Jewitt, 2009). Båda traditionerna har tagit intryck av Hallidays Language as social semiotic (1978). Halliday menar att språkets semiotiska resurser formas av hur människor använder dem för att skapa betydelse. Att betydelseskapandet är funktionellt beskriver han som att det fyller tre metafunktioner samtidigt: det uttrycker något om våra erfarenheter av världen (ideationell metafunktion), relaterar människor till varandra (interpersonell metafunktion) och gör detta på ett koherent sätt (textuell metafunktion).

När Halliday 1985 gav ut den första upplagan av sin Introduction to Functional Grammar formaliserades detta tankesätt. Det skedde genom skapandet av en modell där semiotiska resurser knöts till de olika metafunktionerna, s.k. systemiska nätverk. Exempelvis knöts processer och transitivitet till den ideationella funktionen, språkhandlingar till den interpersonella och informationsstruktur till den textuella. Modellen 
ger en paradigmatisk beskrivning, som formaliserar de semantiska val som konstituerar språkets grammatik.

När Kress och van Leeuwen arbetade tillsammans i Australien började de använda Hallidays sätt att modellera språket som en semiotisk teori användbar även för visuellt betydelseskapande. Det resulterade 1996 i den banbrytande boken Reading Images: The grammar of visual design. Grundidén var att metafunktionerna kunde modelleras i systemiska nätverk även för en visuell grammatik. Metodologin sammanfattas koncist av Jewitt, Bezemer och O’Halloran (2016:49):

1. Developing metafunctionally organized systems.

2. Analysing the text according to the choices that are selected.

3. Interpreting combinations of choices according to register and genre.

SFL-baserad multimodalitetsforskning har blivit något av en grand theory, där formaliseringen av de betydelser som är kopplade till metafunktionerna är utgångspunkten för analysen (Ledin \& Machin, 2018c). På detta vis har alla möjliga typer av kommunikation studerats, såsom webbsidor (Bauldry \& Thibault, 2006; Karlsson, 2002), förpackningar (Wagner, 2015), film (I Tseng, 2013; Bauldy \& Thibault, 2006), musik (van Leeuwen, 1999), bildkonst (O’Toole, 1994), arkitektur (Ravelli \& McMurtrie, 2015), museiutställningar (Insulander, 2010) och gudstjänster (Øierud, 2013).

Denna forskning tar sin utgångspunkt i att modelleringen av metafunktionellt sorterade resurser är giltig för alla modaliteter, inte bara för verbalspråk. Så ses exempelvis nätverket för processer i den ideationella metafunktionen som en semiotisk princip som strukturerar visuellt betydelseskapande, inte minst i fotografier. En materiell process i språket, där typiskt ett verb representerar 
en handling eller händelse, blir visuellt en narrativ process där vi ser något hända, där det finns en vektor (ett visuellt 'verb'), som Kress och van Leeuwen (1996: kap. 3) uttrycker det. Går vi till arkitektur är principen den samma, byggnader antas kunna realisera processer och betydelser (Ravelli \& McMurtrie, 2015:31). Och för varje modalitet eller semiotisk resurs förutsätts det att varje metafunktion är förknippad med systemiska nätverk som specificerar betydelseval. Det är på det viset en visuell (eller arkitektonisk, osv.) grammatik uppstår.

I Reading Images analyseras liknande material som i Hodge och Kress (1988), dvs. tidningar, tidskrifter och läroböcker, liksom konst och fotografier. Också detta är av betydelse för sakprosaforskningen, som nu kunde få detaljerade analysmodeller för att komma åt hur t.ex. en lärobok i biologi kommunicerar. Detta tilltalade många språkvetare, just för att det i detalj gick att säga vilka ideationella (t.ex. processer), interpersonella (t.ex. modalitet) och textuella (t.ex. komposition) betydelser som aktualiserades i den visuella och multimodala kommunikationen. I ett senare avsnitt exemplifierar vi hur multimodala sakprosaanalyser gjorts på denna grund.

Reading Images är en komplex bok, där en rad olika infallsvinklar på visuell kommunikation presenteras och en för sin tid helt ny terminologi myntas. Att den fått ett sådant inflytande beror också på att förenklade läroböcker givits ut. I Sverige är Björkvalls (2009) Den visuella texten en kort och pedagogisk framställning av grundidéerna och internationellt har Machins (2007) Introduction to Multimodal Analysis bidragit till att sprida Kress och van Leeuwens bok, som för övrigt kom i en reviderad utgåva 2006.

Som nämnts har SFL blivit något av en grand theory för multimodalitetsforskning, och Kress och van Leeuwens klassiker är än idag standardverket, ibland genom Björkvalls (2009), Løvlands (2007) och Machins (2007) 
pedagogiska introduktioner. Dagens teoretiska diskussioner handlar bland annat om i vad mån metafunktionerna med systemiska nätverk kan användas för allt sorts betydelseskapande; om musik, förpackningar, kläder, rumsdesign och tidningar kan och bör analyseras med dessa utgångspunkter. Ledin och Machin (2018c) argumenterar för att sådana SFL-undersökningar riskerar att förlora i analytisk skärpa, eftersom huvudsaken lätt blir att etikettera de multimodala texterna utifrån det givna systemet, alltså nätverken knutna till metafunktionerna. Med hänvisning till bland annat Voloshinov (1986/1929) menar de att de materiella förutsättningarna och begränsningarna i olika semiotiska material bör betonas, alltså hur olika semiotiska artefakter afforderar eller bjuder in till visst och begränsar annat slags meningsskapande (Gibson, 1977; Kress, 2010) i olika faktiska kontexter. Ur detta perspektiv blir i stället det intressanta att undersöka vilka betydelser som kan kommuniceras med fotografier men som inte går att kommunicera med skrift (Machin, 2013; jfr Westberg, 2017 i denna tidskrift). Den intresserade hänvisas till den debatt som följde i tidskriften Critical Discourse Studies (med Ledin \& Machin, 2019 som final reply).

\section{Sakprosabegreppets ursprung i ett multimodalt perspektiv}

När språkvetaren Rolf Pipping myntade sakprosabegreppet (1938) så var det en särskilt typ av skriftspråklig stil han hade i tankarna. Utifrån ett funktionalistiskt perspektiv som betonar kommunikativa behov kombinerat med en stark idealisering av rationalitet som kommunikativ grundprincip, definierar han sakprosa - eller 'normalprosa' som han också övervägde att kalla det - som den stil som möter vårt intellektuella uttrycksbehov. Denna stil kontrasterar Pipping med det emotionella behovet, som i sin tur ställs i opposition mot det viljestyrda behovet, vilket Pipping knyter till retoriska behov av att övertyga och argumentera. Han hänvisar inte till den typ av samtida språkvetenskap som vi redogjort för i det föregående, och det finns inga 
spår av Saussures, Bakhtins eller Voloshinovs tankar i hans essäliknande text. Om vi dristar oss till att utföra en metaanalys av stilen i Pippings egen text, så kan man snabbt konstatera att såväl känslor som vilja styrt hans egen textutformning, trots idealiseringen av det rationella. Med emfas hävdar han att mottagarperspektivet är principiellt uteslutet ur sakprosa - intellektuellt arbete förutsätts stå över sådan hänsyn - men i hans egen text (som han alltså klassar som sakprosa) återfinns många appelleringar till en tänkt mottagare. Bland annat drar han ofta med publiken i pronomenet 'vi' och ställer läsaren ett antal frågor. Sett ur detta perspektiv tycks alltså sakprosabegreppets genealogi sakna den precisionsnivå som vi vanligtvis kräver av vetenskapliga begrepp (Tønnesson, u.u.). Pipping relaterar alltså inte heller sakprosabegreppet explicit till de traditioner som har blivit grundläggande referenspunkter för dagens text- och diskursforskning. Trots detta har begreppet visat sig vara användbart och relevant för nordisk - i synnerhet svensk och norsk vetenskap, skola och offentlighet sedan begreppets etablering för ca 80 år sedan.

I Pippings bägge förslag till stilbeteckning - normalprosa och sakprosa återfinner vi efterledet 'prosa' som helt uppenbart är knutet till verbalspråket. Även om Pipping utan tvekan hade skriftspråket i åtanke, så har prosabegreppet aldrig varit reserverat för det skriftliga. Tvärtom härstammar ordet från latinets prosa oratoria, där prosa är en avledning av provorsus, som betyder 'rakt'/'rättfram' på svenska och 'likefram' på norska (ung. straight forward på engelska). Prosa var med andra ord 'rakt' och 'rättframt' talad. Tønnesson reserverar i sin bok Hva er sakprosa (2008) sakprosabegreppet till att endast omfatta skriftliga utsagor. Om begreppet ska omfatta all mänsklig verbal kommunikation (bortsett från fiktionslitteratur) och därmed inkludera det stora och framväxande samtalsanalytiska fältet (Conversation Analysis), så går det dock att argumentera för att forskningsområdet helt skulle kunna bortdefiniera sig självt genom sin gränslöshet. När Hva er 
sakprosa skulle revideras år 2012 utvidgade emellertid Tønnesson definitionen till att också omfatta muntliga texter, men med förbehållet att texterna måste vara offentligt tillgängliga, exempelvis i form av politikertal och radiosändningar (s. 34).

I Tønnessons definition ingick också en tudelning mellan litteratur med en klar författar-instans och som är sprungen ur en litterär institution "litterär sakprosa" - och "funktionell sakprosa" som är den typ av litteratur som finner sitt existensberättigande inom de samhälleliga institutionerna och som spänner från genrer såsom bruksanvisningar och reklam till politiska tal och lagtexter. Ur detta perspektiv är sakprosa inte längre en stil, utan texter som kännetecknas av att dess mottagare använder och läser dem som direkta yttranden om verkligheten och dess beskaffenhet. Även om Pippings stilorienterade definition från 1938 var vid - sakprosa som saklig stil pekar mot en stor mängd genrer - så är Tønnessons definition från 2008/2012 radikalt mycket vidare: den omfattar all offentligt tillgänglig prosa - talad och skriven - utanför de skönlitterära institutionerna.

\section{Prosa med många modaliteter}

Som redan nämnts är det en vedertagen uppfattning att verbalspråket alltid ledsagas av andra semiotiska resurser - typografi, layout, illustrationer, papperskvalitet, bokbindningsformer, format och mycket mer. Frågan är då vilket utrymme denna insikt făr i den sakprosadefinition som presenterats ovan? I fallet muntlig sakprosa har retoriken alltid hävdat att muntligt tal måste förstås tillsammans med gestik och mimik samt i relation till den plats där talet framförs och med hänsyn till den teknik med vilken talet förmedlas (Kendon, 2004). Som framgått har (social)semiotiska perspektiv också betonat vikten av att studera kommunikation ur såväl ett symboliskt som ikoniskt perspektiv, och följaktligen måste studier av skriftlig och muntlig 
sakprosatext ta sådana aspekter i beaktande. I praktiken har så sällan varit fallet, först och främst på grund av att textforskare, oavsett om de varit lingvister eller (skön)litterärt orienterade, har haft sin primära kompetens i studier av verbalspråk, något som exemplifieras av det första norska sakprosaprojektet (Grepstad, 1997; Johnsen \& Eriksen, 1998).

Sedan nya tryck- och sättningstekniker gjort det enklare och billigare att producera illustrerade texter, runt förra sekelskiftet, och inte minst i samband med internets och de sociala mediernas intåg, har den multimodala textproduktionen blivit normalfallet, också för sakprosatexterna. Samtidigt har verktygen för multimodal textdesign blivit allmänt tillgängliga, exempelvis via sociala medier. Merparten av vardagens institutionella texter är alltså multimodala i bemärkelsen medvetet designade som multimodala helheter. En analys som inte tar hänsyn till detta kan med rätta kritiseras för att vara underspecificerad (Spitzmüller \& Warnke, 2011: 79; Westberg, 2016: 33), dvs. för att skapa mindre förståelse för studieobjektet än vad som är möjligt med tillgängliga metoder och material.

Samtidens kommunikationspraktiker kräver helt enkelt av sakprosaforskaren att multimodalt meningsskapande beaktas, förutsatt att målsättningen är att förstå hur betydelseskapande val i text hänger samman med och påverkar textens roll i en eller flera institutioner. Idag, år 2019, samverkar ljud och levande bilder med skriftmodaliteten i vardagens texter (tänk t.ex. informationstexter från myndigheter likväl som Instagramtexter), och inte sällan är övergångarna mellan skrift, tal och musik många och sömlösa.

För sakprosaforskningen är verklighetens beskaffenhet på sätt och vis en utmaning, eftersom många av oss som bedriver denna forskning framförallt har kompetens i språk och litteratur. Men i stället för att se vår akademiska hemvist som begränsande, manar vi snarare till dialog mellan olika 
discipliner (jfr Machin, 2013 för en liknande hållning). Om vi trots den samtida sakprosans multimodala karaktär väljer att endast fokusera på verbala resurser i våra analyser, så kommer vi tveklöst att hamna i en återvändsgränd när vi söker efter ny kunskap och teoretisk utveckling. I diskussionen om sakprosabegreppets praktiska användbarhet måste vi alltså göra klart huruvida begreppet exkluderar andra medier och semiotiska modaliteter än dem vi av hävd associerar med 'prosa' och om det också exkluderar andra kommunikativa praktiker, sådana som kommer till uttryck när vi - för att föregripa ett senare exempel i denna artikel - befinner oss på en flygplats, eller för den delen yttranden som varken har textstatus eller är offentliga, men som ingår i institutionella textkedjor inom exempelvis vården (Karlsson \& Landqvist, 2018).

Ur ett textanalytiskt perspektiv menar vi att sakprosabegreppet har fortsatt relevans, dels för att efterledet prosa, i kontrast till begrepp som text, yttrande, kommunikation och diskurs, riktar uppmärksamheten mot kvaliteter $i$ uttrycket. Dels menar vi att förledet sak är fortsatt viktigt, eftersom det riktar ljuset mot prosans sakfråga och relation till verkligheten, dvs. prosans roll inom en institution som ett yttrande om verkligheten.

Tanken på multimodala uttryck som yttranden om verkligheten som får sin betydelse i relation till det kontextuella går att härleda till socialsemiotisk såväl som till diskursanalytisk teori (t.ex. Hodge \& Kress 1988; Halliday, 1978; Kress, 2003; Kress \& van Leeuwen, 2001; Fairclough, 1992), men också hela vägen tillbaka till vad Aristoteles skriver i sin Poetik (kap 9 i Butchers översättning) om att det inte är formen utan stoffets förhållande till verkligheten som avgör om vad som är poesi.

Sakprosaforskningens intresse för hur texten förhåller sig till verkligheten delas alltså av multimodalitetsforskningen, men där den internationella 
multimodalitetsforskningen har tenderat att rikta det analytiska ljuset mot journalistiska, politiska, pedagogiska och kommersiella diskurser, har sakprosatraditionen snarare riktat intresset mot kommunikativa praktiker med relevans för medborgerligt samhällsdeltagande och mot demokratifrågor. Detta syns bland annat i Svenssons tidiga studie av fattigvårdens diskursordning (2001) och i nyare projekt som ansluter till sakprosatraditionen, exempelvis i Björkvall och Nyström Höögs forskningsprojekt om statliga myndigheters värdegrundstexter (t.ex. Nyström Höög, 2015). Det går alltså att urskilja ett intresse för prosans betydelse i en demokratisk textkultur inom sakprosaforskningen, vilket delvis särskiljer traditionen från den internationella multimodalitetsforskningen.

Inom semiotisk och multimodal forskning har många begrepp utvecklats för att fånga tänkandet om hur texter förhåller sig till den så kallade verkligheten. Hit hör Barthes (1963) klassiska distinktion mellan denotation och konnotation, dvs. mellan det avbildade (t.ex. en vit rockärm) och de idéer och värden som det avbildade representerar (t.ex. 'expertkunskap', 'auktoritet'). Även Kress (2003:46) distinktion mellan redundans och funktionell specialisering kan nämnas. Semiotiska resurser blir i sociala praktiker specialiserade såtillvida att de lämpar sig för visst (men inte annat) slags betydelseskapande. Fotografier, diagram, skrift, layout osv. har alla sina användningsområden i olika sammanhang. Ska vi exempelvis beskriva hur en person ser ut för någon som inte vet det kan ett fotografi vara bra - det tillåter oss att direkt känna igen personen. En sådan beskrivning är inte lika lätt att göra med språk, som bättre lämpar sig för att beskriva karaktärsdrag eller ge en biografisk bakgrund. Samtidigt är semiotiska resurser redundanta eller överlappande i faktiska multimodala texter; då vi beskriver en person med ett fotografi tillsammans med en skriven text får vi delvis redundanta betydelser. 
Kress (2009:208) understryker även situationens och kulturens betydelse för multimodalt betydelseskapande, bl.a. när han skriver att "it becomes essential to take each occassion of communication as new (...) In other words, there is now a permanent need for a rhetorical stance”. Med Cullers ord är relationen mellan text och verklighet direkt kopplad till kontexten: "Nonfictional discourse is usually embedded in a context that tells you how to take it” (2000:31). Kress och Cullers fokus på litteratur som tilltalar snarare än omtalar verkligheten knyter delvis an till sakprosaforskningens intresse för makt och demokratifrågor. Å ena sidan finns en tendens att framhäva demokratiaspekten utifrån tanken om meningsskapande som medel för deltagande och emancipation, inte minst i pedagogiska sammanhang och i relation till skolelevers meningsskapande (jfr t.ex. Björkvall \& Jacquet, 2014; Westberg \& Björkvall, 2019). Sådana strävanden kopplat till skrivande och textdesign finner tydligt ideologiskt stöd i The New London Groups manifest om litteracitet och pedagogik (NLG, 1996) där Gunther Kress, tillsammans med bl.a. Carey Jewitt och Jeff Bezemer, är tongivande forskare. Å andra sidan medför fokuset på mycket lästa texter som fungerar som utsagor om verkligheten ett intresse för delvis andra demokratifrågor, särskilt sådana som betonar förutsättningar för medborgerligt deltagande.

Ett svenskt exempel på detta är Lind Palickis (2010) avhandling, som undersöker vilka mottagare som inkluderas och exkluderas när Försäkringskassan kommunicerar med nyblivna föräldrar i prosa. Ett danskt exempel är Hanghøj, Lieberoth och Misfeldt (2018) som undersöker hur datorspel kan bidra till inkludering. I en interventionsstudie i en högstadieklass visar de att studenter med olika sociala problem känner sig mer inkluderade i skolan och klassgemenskapen när datorspel ingår i undervisningen, och detta gynnar deras lärande av traditionella skolämnen. Ur detta perspektiv kan alltså sakprosaforskningen å ena sidan erbjuda multimodalitetsforskningen ett fokus på texter som är bärande för samhällets institutioner (Lind Palicki), och å andra 
sidan gör mulitmodalitetsforskningen det möjilgt att uppmärksamma hur populärkulturella artefakter, som datorspel, kan användas för att inkludera och stötta skolframgång (Hanghøj, Lieberoth \& Misfeldt, 2018; Björkvall \& Jacquet, 2014; Westberg \& Björkvall, 2019).

\section{Den nordiska sakprosaforskningen blir multimodal}

När sakprosaforskningen tog form på 1990-talet kom den, trots sitt ursprung i språkvetenskap, textlingvistik, idéhistoria, litteraturvetenskap och retorik, på olika sätt att knytas till den utveckling inom multimodalitet och socialsemiotik som skisserats ovan.

\section{Svensk sakprosaforskning}

När projektet Svensk sakprosa (Melander \& Olsson, 2001; Englund \& Ledin, 2003) startade 1996 var det med syftet att belysa det mycket lästa från 1750, då en mer utbredd skriftkultur på svenska tar form, och fram tills idag. Den enkla motiveringen var att sakprosa formar människors liv, deras handlande och tänkande. Det fanns ingen specifik inriktning mot visuella analyser, men det visade sig snart att det visuella varit centralt i betydelseskapandet genom texthistorien och inte 'uppstod' i och med den ökade visualiseringen under 1900-talets andra hälft. Inte minst utvecklas under 1800-talet ett bildsamhälle på så sätt att det blev möjligt att massprida bilder (Johannesson, 1978).

Två teman som belystes i det svenska sakprosaprojektet var dels skolans och folkbildningens texter, dels veckopressen, som är en av de mest masspridda publikationstyperna i sakprosahistorien. Veckopressen är knuten till det borgerliga och liberala genombrottet på 1800-talet och till seklets teknologiska landvinningar. Till det förra hör t.ex. krav på yttrandeoch näringsfrihet, och till det senare allt från nya trycktekniker till järnvägar. 
En konsekvens är att en ny press uppstår för en ny borgerlig publik som hade tid att läsa (Ledin, 1998, 2000). Ett uttalat mål var att förena nytta med nöje, och det visuella var viktigt. De tidiga tidningsnamnen innehöll gärna ordet 'illustrerad' och efter sekelskiftet 1900 blir "den kolorerade veckopressen" en fast fras.

En föregångare är Lars Johan Hierta, presshistoriskt mest känd som Aftonbladets grundare, och hans Lördags-Magasinet, utgivet 1836-38 och 1842. Sakprosa och folkbildning var huvudsaken, och spännande upptäcktsfärder samsades med naturvetenskapliga utredningar. Lördags-Magasinet var banbrytande som multimodal publikation, vilket möjliggjordes av att tidningen lyckades skaffa ensamrätt till de engelska trästicken, eller de xylografiska gravyrplåtarna av hårt trä, som gjorde det möjligt att massproducera bilder och även trycka dem tillsammans med text (Johannesson, 1978).

Ett exempel på tidningens multimodala produktion ges i figur 1: till vänster ser vi ett omslag som illustrerar den dramatiska upplösningen av numrets reseskildring, som med dåtidens språkbruk tillhörde naturalhistorien och lade särskild vikt vid att reda ut vad Boa Constrictor är för djur. I en passage i artikeln, där en reseskildring citeras, får vi veta hur en matros somnar i båten samtidigt som en "ofantlig Boa Constrictor" kastar sig över båten och honom. Som bilden visar kommer besättningen tillbaka, och "genom ett lyckligt afhuggande av dess stjert” kunde matrosen räddas.

Det är förstås ett semiotiskt motiverat val (jfr Kress, 2010) att placera den detaljerade illustrationen av berättelsens höjdpunkt på framsidan. Följer vi Kress och van Leuuwen (1996) är detta en narrativ bild, där olika vektorer eller påverkanslinjer utgår från deltagarna. Till vänster finns en man som riktar en åra mot boan. En annan svingar en yxa, och till höger syns två män 
med yxa respektive kniv. Allt detta motsvarar processtypen aktion. Med Kress och van Leeuwen (1996) kan vi också säga att modaliteten är naturalistisk, alltså att världen huvudsakligen avbildas som vi ser den med blotta ögat. Det märks på detaljskärpan, där även bakgrunden tecknas tydligt.

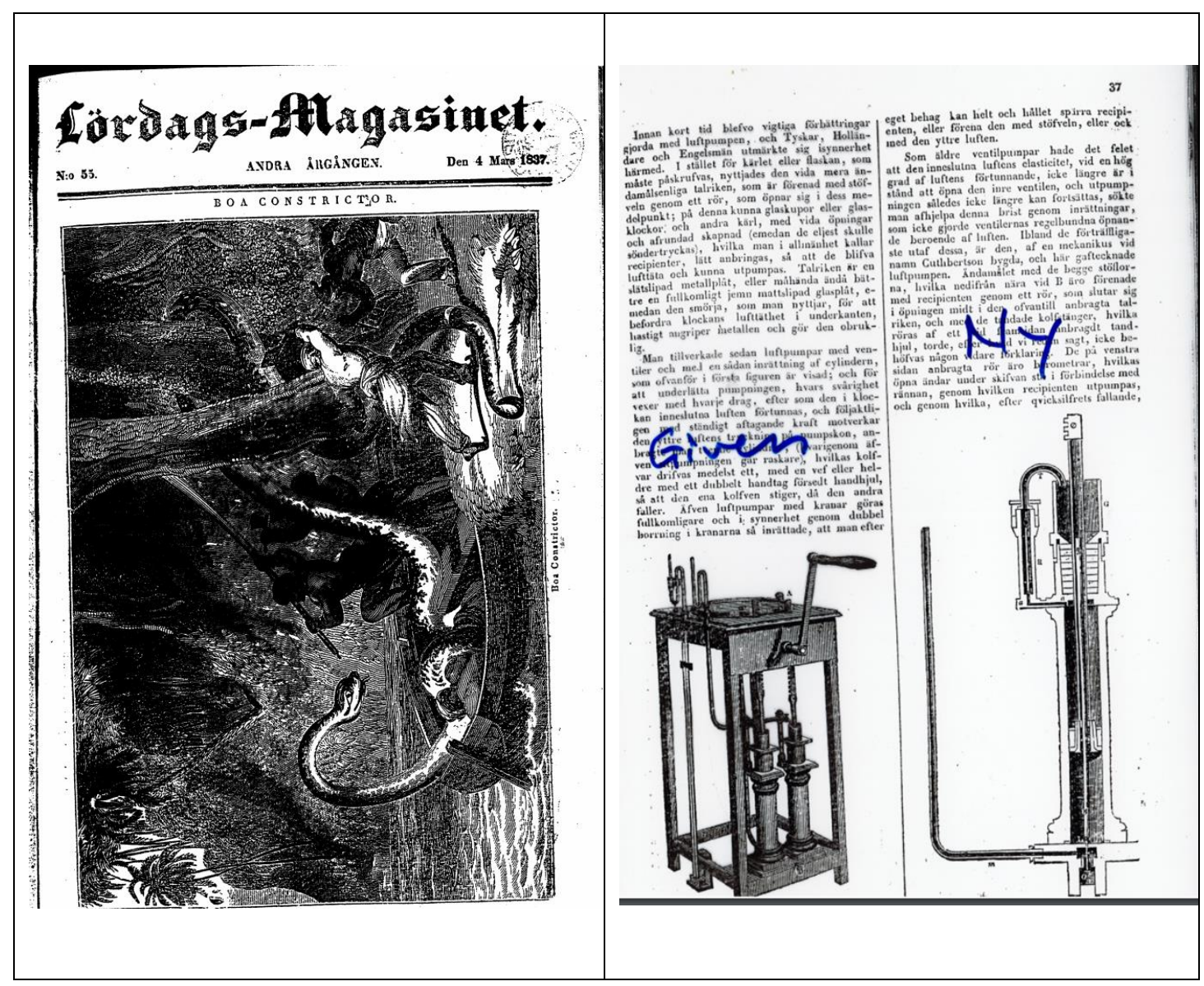

Figur 1. Två olika sidor från Lördags-Magasinet 1837. Till vänster ett omslag och till höger illustrationer ur en populärvetenskaplig artikel om luftpumpen

Till höger ser vi två andra typer av illustrationer: representationerna avbildar en luftpump, som, genom sin förmåga att skapa vakuum, varit viktig i naturvetenskapens utveckling. Den vänstra har inslag av naturalistisk modalitet, även om den inte har någon bakgrund och avbildar en generisk luftpump. 
Det finns djup, detaljer och ljusskiftningar. I den högra bilden är den abstrakta vetenskapliga modaliteten normen. Den vardagliga verkligheten, som vi tar in med ögat och sinnen, är ointressant. I stället fokuseras de generella principerna för hur något fungerar - det vi ser är en cylinder i pumpen. Att det blivit möjligt att samlayouta illustrationer och skriftspråk tillåter också att sidans horisontella dimension utnyttjas. Med Kress och van Leeuwens (1996) terminologi introduceras luftpumpen med en mer naturalistisk modalitet som 'given', till vänster, medan den vetenskapliga bilden blir den 'nya' mer oväntade informationen till höger.

Fortsätter vi genom 1800-talet ser vi hur illustrationer vinner mark inte bara i pressen, utan också i sådana texter som är kopplade till skola och folkbildning. Med den allmänna folkskolans införande, i Sverige 1842, kom vidare läroböcker att bli en masspridd genre. Ekvall (2001) följer deras utveckling till nutid och visar hur illustrationer, inte minst av den abstrakt-vetenskapliga karaktär som vi såg ovan blir en del av det multimodala betydelseskapandet. Pettersson (2000) tar sig på ett liknande sätt an samspelet mellan text och bild i uppslagsböcker under 1900-talet, där ett huvudresultat är att antalet sidor med bild blir fler över tid. Westberg $(2016,2017)$ visar hur rådgivande och informativa texter kring föräldraskap genomgår en markant visualisering från slutet av 180o-talet till 2000-talets början, och hur denna visualisering förstärker en idé om föräldraskap som en kvinnlig praktik. I sin analys av preventivmedelsbroschyrer från slutet av 1800-talet till 1995 visar Byrman (2001) hur det symboliska fotografiet vinner mark. Bilden till vänster i figur 2 visar det kvinnliga könsorganet i genomskärning med en abstrakt modalitet som rimmar med den aktuella broschyrens fokus på könsorganens anatomi och fysiologi. Fotot till höger föreställer en knoppig och daggfuktig röd tulpan, hämtad från broschyren Love Power Magazine från 1995, med bland annat Riksförbundet för sexuell upplysning som avsändare. Att fotot inte ska tolkas bokstavligt utan symboliskt är uppenbart; i broschyren används fotografier av 
blommor mot en vit bakgrund genomgående för att symbolisera könsorgan och sex.

Figur 1. Anatomisk plansch pá

kvinnans könsorgan.

Källa: Försigtighetsmătt

¡ Äktenskapet (1886, s. 13)
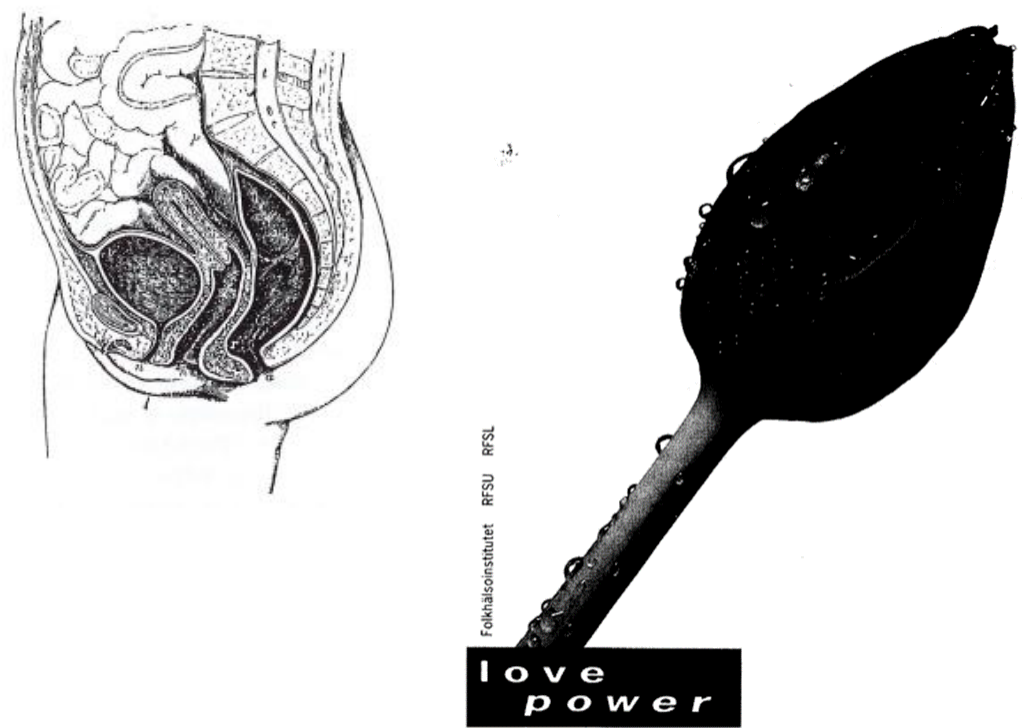

Figur 6. Baksidan pả Folkhälsoinstitutets, RFSU:s och RFSL:s broschyr, Love power magazine $(1995,5.52)$, som propagerar för kondomanvändning.

Figur 2. Två illustrationer hämtade från preventivmedelsrådgivning, den vänstra från 1886 och den högra från 1995

Just det symboliska fotot hör sedan några decennier inte bara till reklamvärlden utan till samhällsinformation i allmänhet (jfr Ledin \& Machin, 2018: kap. 3), där dekontextualiserade foton, ofta med vit bakgrund, noggrant ljussatta objektet och mättade färger förenklar och förskönar världen för att ge positiva associationer till något - i reklam t.ex. en bil eller en parfymflaska. Den som söker på någon av de många kommersiella bildbanker som finns, t.ex. Getty Images, hittar snabbt ett överflöd av exempel (jfr Machin, 2004). 


\section{Norsk sakprosaforskning}

Det första norska sakprosaforskningsprojektet, Norsk Sakprosa (Grepstad, 1997; Johnsen \& Eriksen red., 1998: bd. 1 och 2) var huvudsakligen inriktat mot studier av verbalspråk. 'Sakprosa' har inte i någon vidare bemärkelse heller använts för att beteckna varken en disciplin, ett perspektiv eller ett studieobjekt i de nordiska miljöer som sedan millennieskiftet de facto har drivit fram en multimodalt inriktad sakprosaforskning, dvs. kontextuellt och funktionellt orienterade undersökningar av ickelitterära texter. Begreppet sakprosa har emellertid aktualiserats i multimodalt orienterade forskares genrebetonade diskussioner. Vi ska här ge fyra exempel på sådana tematiseringar.

I sin avhandling om tidningsframsidor pekar Veum (2008:28) på Berges diskussion om sakprosabegreppet $(2001,2002)$ och slår fast att "Tekstvitskapen studerer tekstar som på norsk gjerne går under fellesnemninga sakprosa” (ibid.). Med andra ord särskiljer Veum sakprosa som en 'norsk' textkategori. I kontrast till detta använder Frøjd (2018), i sin undersökning av texter i den norska elevinsamlingsorganisationen Operasjon Dagsverk, sakprosabegreppet för att göra taxonomisk skillnad mellan funktionell och litterär prosa. Frøjd menar att Tønnessons "definisjon av sakprosa har fătt god grobunn i tekstforskningen" och genreplacerar de undersökta texterna utifrån distinktionen mellan litterär sakprosa, dvs.”forlagspubliserte tekster med navngitte forfattere"och funktionell sakprosa, som "har en kollektiv forfatterforståelse og er rettet inn mot sin funksjon.” (Frøjd, 2018: 7). Brinch Jørgensen (2016) intar i sin avhandling om visuell retorik i stadsutveckling en mer diskuterande hållning:

Sakprosaen fordeler seg da i litterær sakprosa og funksjonell sakprosa (Tønnesson, 2012: 33-34). Sett fra et klassisk retorisk synspunkt er ikke dette et godt skille ettersom man i den klassiske 
retorikken har utviklet teori og regler for den gode praksis når det gjelder all hensiktsbasert tale, og herunder hører det å ta i bruk den stil og de troper og figurer som på best vis fremmer hensikten. Men sett fra et nyretorisk synspunkt hvor man har økt status til kairos, eller den retoriske situasjonen, gir en institusjonell kategorisering bedre mening (Brinch Jørgensen, 2016:53-54).

Under avsnitten Socialsemiotik och Systemisk-funktionell lingvistik ovan har vi med kritisk ansats pekat ut en internationell tendens att etablera multimodalitet som en ny vetenskaplig doxa, där forskningen delvis prioriterat att fullända en grammatik framför att besvara mer pressande forskningsfrågor. Denna tendens har dock i liten grad präglat de sista 20 årens forskning i den norska sakprosamiljön, vilket illustreras med fyra avhandlingar nedan:

I sin avhandling Naturfagets tause stemme fra 1999 (2001) undersöker Knain implicit ideologi i läroplaner och läroböcker. Med tydlig inspiration från den då nyutkomna Reading images (1996) lägger han stor vikt på bildanalyser och avslutar en av sina analyser på följande sätt:

Teksten er dominert av abstrakte prosesser uten menneskelig deltakelse, og hvor mennesker er omtalt i helt generelle vendinger. Bildene er preget av handling, av konkrete mennesker som gjør noe i en eller annen kontekst. En videre analyse peker mot at dette ikke er et brudd med tekstens ideologi, men snarere utfyller og styrker bildematerialet L93s [læreplanens] ideologiske innhold (s. 140).

Avhandlingen besvarar samhälleligt aktuella frågor med stöd i SFLtraditionen och bidrar med ny kunskap om bilders meningspotential. 
Begreppet multimodalitet används inte i denna tidiga studie, men står däremot i centrum i Veums avhandling nio år senare: Avisas andlet. Førstesida som tekst og diskurs. Dagbladet 1925-1995 (2008). Här avslöjas radikala förändringar för textnormer, vilket bland annat summeras enligt följande:

Min analyse [...] viser [...] at førstesidene på byrjinga av 1900-talet var komponerte ut frå eit lesemønster som tok utgangspunkt i verbalspråket. Mot slutten av 1900-talet er denne strukturen blitt forlate til fordel for eit lesemønster der ulike semiotiske ressursar i langt større grad samverkar i meingingsskapinga. Avisførstesidene blir ikkje lenger skrivne, men 'designa' og multimodalt artikulerte (s. 140).

Øierud tar sig an egenfilmade gudstjänster i Gudstjenesters kommunikasjon og modelldeltakere (2013). Avhandlingen besvarar centrala praktiskteologiska frågor om gudstjänsten som en meningsskapande helhet. För att förstå gudstjänsten som en multimodal händelse genomför Øierud inte bara en multimodal, utan i det närmaste en multisensorisk analys, där gudstjänstens olika semiotiska resurser rangordnas i ett 'sanseinntrykkshierarki'. Hon har som ansats att beskriva gudstjänstupplevelsen utifrån aktörens perspektiv, och studien visar att auditiva resurser i form av musik är särskilt viktiga ur detta perspektiv.

Juuhl undersöker i sin avhandling Det mykje skrivne. Ei undersøking av ungdoms digitale tekstar i skule og fritid som situerte, retoriske handlingar (2014) etos i ungas skrivande, och frågan är om det finns ett sammanhang mellan (obligatoriskt) skrivande i skolan och (frivilligt) fritidsskrivande, eller om detta är isolerade ekologier. Studien visar att skrivande i bloggar och i andra sociala medier är centralt för ungas skrivande, och Juuhl presenterar originella analyser av färganvändning och komposition. Den multimodala 
forskningstraditionen utgör en självklar bakgrund, men analysen genomförs med ideografisk begreppsapparat snarare än med ett nomotetiskt multimodalitetsteoretiskt ramverk.

\section{Tidskriften Sakprosa}

Även om multimodalitet, som vi har sett, var ett viktigt perspektiv i den svenska sakprosaforskningen, som i sin tur inspirerade den norska forskningsmiljön såväl teoretiskt som metodiskt, så har relativt få utpräglat multimodala studier publicerats i den föreliggande samnordiska tidskriften Sakprosa sedan starten 2009. Å andra sidan har variationen varit stor, både när det gäller metod, forskningsfrågor och de typer av multimodala texter som har studerats. Från Sverige har Ledin (2015) analyserat listans och tabellens semiotik från tidiga skriftkulturer till idag, och Westberg (2017) frilagt moderskapsdiskurser i bl.a. veckotidningar och reklam från 1870- till 2010-talet. Karlsson och Landqvist (2018) analyserar samtida hälsokommunikation så som den praktiseras genom kedjor av medier och modaliteter och Blåsjö, Johansson och Jonsson (2019) studerar digitala kalendrar genom medierad diskursanalys. Från Danmark analyserar Cortsen (2016) tecknade sakprosaserier med betoning på vad som kan skapa god kunskapsförmedling, och Ulbæk (2016) studerar argumentationsdynamik i dialogisk radio. Artiklar på norska är Veums (2010) studie av tidningsframsidor med vikt på diakron utveckling, Michelsens (2010) undersökning av modelläsare på en bokklubbshemsida, Kvåles (2018) analys av bedömningsscheman i förskolan, med fokus på hur formens multimodala design positionerar formuläranvändarna och Løvlands (2014) analys av på vilket vis illustrationer i samspelet med verbaltext bidrar till verklighetsframställning i upplysningslitteratur. 


\section{Mot ett vidgat, multimodalt sakprosabegrepp: Två exempel}

Vi har visat att sakprosabegreppet har sina rötter i annan tid då skriftspråket hade en självklar särställning i samhällets sakförmedling, även om, som vi vid det här laget upprepat många gånger, resurser som typsnittsvariation, teckenstorlek eller textmaterialitet alltid har bidragit till multimodalt betydelseskapande. Idag fyller en rad olika typer av texter och semiotiska praktiker de funktioner som den traditionella sakprosan har haft, som direkta yttranden om verkligheten och dess beskaffenhet.

Dagens situation kräver ett vidgat sakprosabegrepp om begreppet ska ha fortsatt relevans. Karlsson och Landquist (2018) argumenterar för att exempelvis diskussionsforum på nätet och läkares muntliga information måste inkluderas i sakprosadefinitionen eftersom de fungerar som viktiga arenor för offentligt kunskapsbyggande. Här vill vi fortsätta Karlssons och Landqvists argumentationslinje och visa hur ett multimodalt förhållningssätt kan vidga sakprosabegreppet utan att just prosan blir central. Vi vill skjuta fram det funktionsorienterade och närma oss andra semiotiska praktiker som fyller samma (eller liknande) funktion som sakprosa brukar fylla.

Ett sätt att göra det är med hjälp av begreppet genre, som just fokuserar på texters funktion som social eller professionell handling (Swales, 1990; Bhatia, 1993). Genre är inget nytt begrepp inom sakprosaforskningen - tvärtom har det präglat åtminstone svensk sakprosaforskning (Berge \& Ledin, 2001: Ledin, 1996). Här använder vi det för att rikta ljuset mot empirier och praktiker som fyller liknande sociala och kommunikativa funktioner som prosan men med andra semiotiska material och affordanser (van Leeuwen, 2005; Jewitt, 2014; Björkvall, 2018) - det vill säga inneboende möjligheter 
och begränsningar i olika semiotiska material. Våra exempel är hämtade från två aktuella forskningsprojekt, om värdegrunder och flygplatser. 3

\section{Exempel 1: Värdegrund som film}

Inom projektet "En ny genre och dess arkeologi: Svenska myndigheters värdegrunder” har över 200 värdegrundstexter (ung. värdedokument; platform of values på eng.) från statliga myndigheter undersökts. De fyller alla samma funktion; de ingår i en praktik som man kan kalla "att göra värdegrund”, där samtliga anställda inbjuds att diskutera texterna och att förhålla sig till de positiva diskursiva identiteter som där erbjuds. Värdegrundstexten har en speciell status i den praktiken, inte bara som del i aktiviteten, utan också som symbol för den, och som ett kvitto på att myndigheten bedriver värdegrundsarbete (se t.ex. Nyström Höög \& Björkvall, 2018; Björkvall \& Nyström Höög, 2019). Med utgångspunkt i text och praktik kan vi alltså säga att värdegrunden är en genre, ett sätt att handla. En lista med värdeord är ett obligatoriskt inslag, men i övrigt kan texternas utformning och inramning variera. Ett viktigt krav är att värdeorden är fristående, och inte organiseras syntaktiskt som språkhandlingar, eftersom fristående ord inbjuder till diskussion om ordens betydelse. Det är de fristående ordens affordans, om man så vill. Funktionen att öppna för diskussion är viktig i värdegrundsgenren och kan realiseras med olika modaliteter. Några värdegrunder är tryckta broschyrer, andra är affischer eller webbsidor, och några få är faktiskt filmer.

\footnotetext{
3 Värdegrunder studeras i projektet "En ny genre och dess arkeologi. Svenska myndigheters värdegrundstexter" (RJ P15:0119). Flygplatser studeras i projektet "Flyplatskommunikation", som inkluderar forskare från i svenska och nederländska vid Örebro och Stockholms universitet.
}

Ledin, Nyström Höög, Tønnesson och Westberg

Sakprosa.no 
I en av de filmer som finns i materialet flyter värdeorden in i bilden, ett efter ett, mot en bakgrund där myndighetens kärnverksamhet illustreras i bild och ljud. I slutet av filmen förekommer värdeorden samlade, som ett slags lista. Vanligare utformningar är broschyrer, där färg, text och bild samspelar i betydelseskapandet. Färg skapar till exempel sammanhang genom sådana broschyrer och bilderna understödjer skriften, så att de positivt laddade värdeorden förstärks eller återspeglas i bilder av människor som ser glada ut. I en av broschyrerna finns en bildserie som visar en grupp av medarbetare under flera olika situationer på arbetet. Bildserien kan förstås som ett narrativ, som på motsvarande sätt som de fristående orden öppnar för diskussion, och blir alltså en viktig resurs i värdegrundsarbetet. Exemplen visar hur genren inte låter sig avgränsas till en modalitet - skrift - utan överskrider modaliteternas gränser och låter praktiken "att göra värdegrundsarbete” spänna över en rad olika uttryckssätt. Utan det multimodala perspektivet går inte sakprosagenren värdegrund att begripliggöra.

\section{Exempel 2: Rumsliga betydelser på en flygplats}

Vårt andra exempel antar en mer radikal förståelse av genre som multimodalt koncept. Det är hämtat från ett forskningsprojekt som med inspiration från spatial diskursanalays (Ravelli \& McMurtrie, 2015; Stenglin, 2004) undersöker den internationella flygplatsens design som text och genre. Med stöd i en 'textkorpus' bestående av sju olika flygplatser, kan vi visa hur den internationella flygplatsen på ett genreliknande vis byggs upp av mer eller mindre nödvändiga steg: ankomsthall^ ${ }^{\wedge}$ säkerhetskontroll^ avgångshall och shopping^ gatelounge (jfr Jaworski \& Thurlow, 2013:159). Dessa steg är nödvändiga för att flygplatsen ska uppnå ett av sina primära syften: att etablera förutsättningar för välbefinnande och kontroll i en potentiellt hotfull och stressande miljö. Här är det ännu tydligare än i de statliga värdegrunderna att vi inte längre har att göra med 'prosa', men vi menar ändå att 
flygplatsens rumslighet fyller kommunikativa funktioner som tydligt liknar sådana som vanligen förknippas med sakprosa.

Genom sin tydliga rumsliga dirigering - påbjuden rörelseriktning indexeras bl.a. med pilar, olikfärgade golv och strategisk ljussättning - strävar flygplatsen efter att åstadkomma kommunikativa effekter liknande den typiska sakprosans. Genom att 'läsa' rummets uppmaningar och följa dess påbjudna affordanser kan resenären vara trygg och behöver inte oroa sig för att göra fel. Dessutom ger den rumsliga designen råd och informerar i fråga om var och vart vi ska gå och var vi ska sitta. Här fyller t.ex. golvmaterial en viktig funktion: heltäckningsmattor används i gateloungen för att affordera 'stillhet' och 'icke-rörelse', medan hårda stengolv i kombination med riktningsutpekande linjeformer bjuder in till rörelse. På så vis eftersträvar flygplatsens rumsliga betydelse en rådgivande funktion som liknar den hos mer prototypiska sakprosatexter, exempelvis rådgivande myndighetstexter.

Flygplatsens funktion att främja känslor av kontroll och välbefinnande är dessutom avhängig av rummets genrelika kohesion mellan slutna och öppna rum. På Arlanda flygplats är tex. ankomsthallen (se figur 3) ett öppet rum med högt i tak som tillsammans med rundade arkitektoniska former och mycket ljusinsläpp afforderar, dvs. bjuder in till, känslor av 'frihet' och 'obundenhet'. 4

4 Vi vill tacka Swedavia som givit oss tillstånd att använda och publicera fotografierna i Figur $3-7$.

Ledin, Nyström Höög, Tønnesson och Westberg

Sakprosa.no 


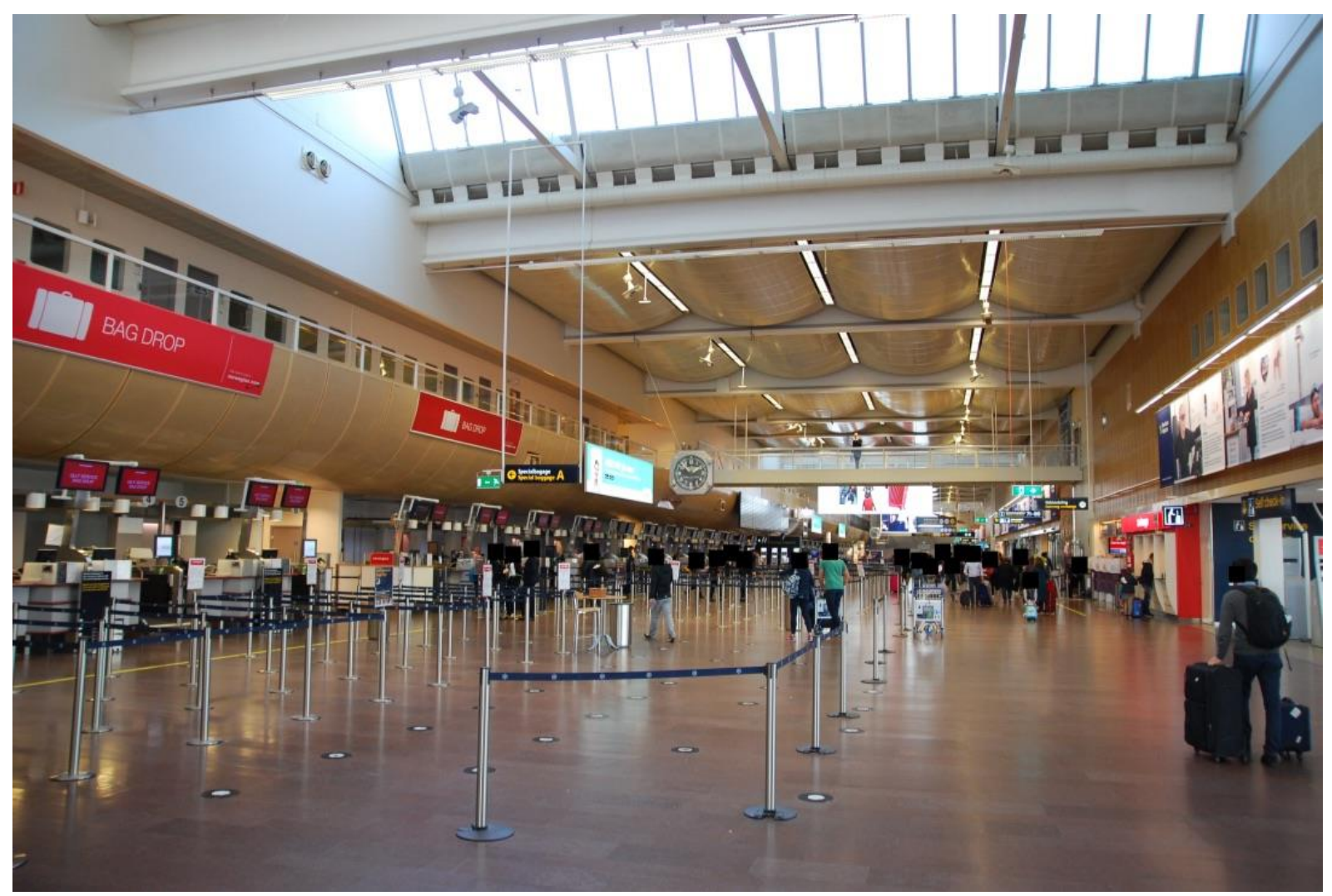

Figur 3. Ankomsthall, Arlanda flygplats

Efter ankomsthallen slussas resenärerna till säkerhetskontrollen (se figur 4), som är ett slutet, rektangulärt och trångt rum med få och dämpade färger utan ljusinsläpp, dessutom med pilar och stolpband som visar var kroppar (inte) ska köa. I kontrast till ankomsthallens obundna rumsdesign afforderar säkerhetskontrollens rumsliga resurser snarare 'kontroll' och 'trygghet', men möjligen också 'instängdhet'. 


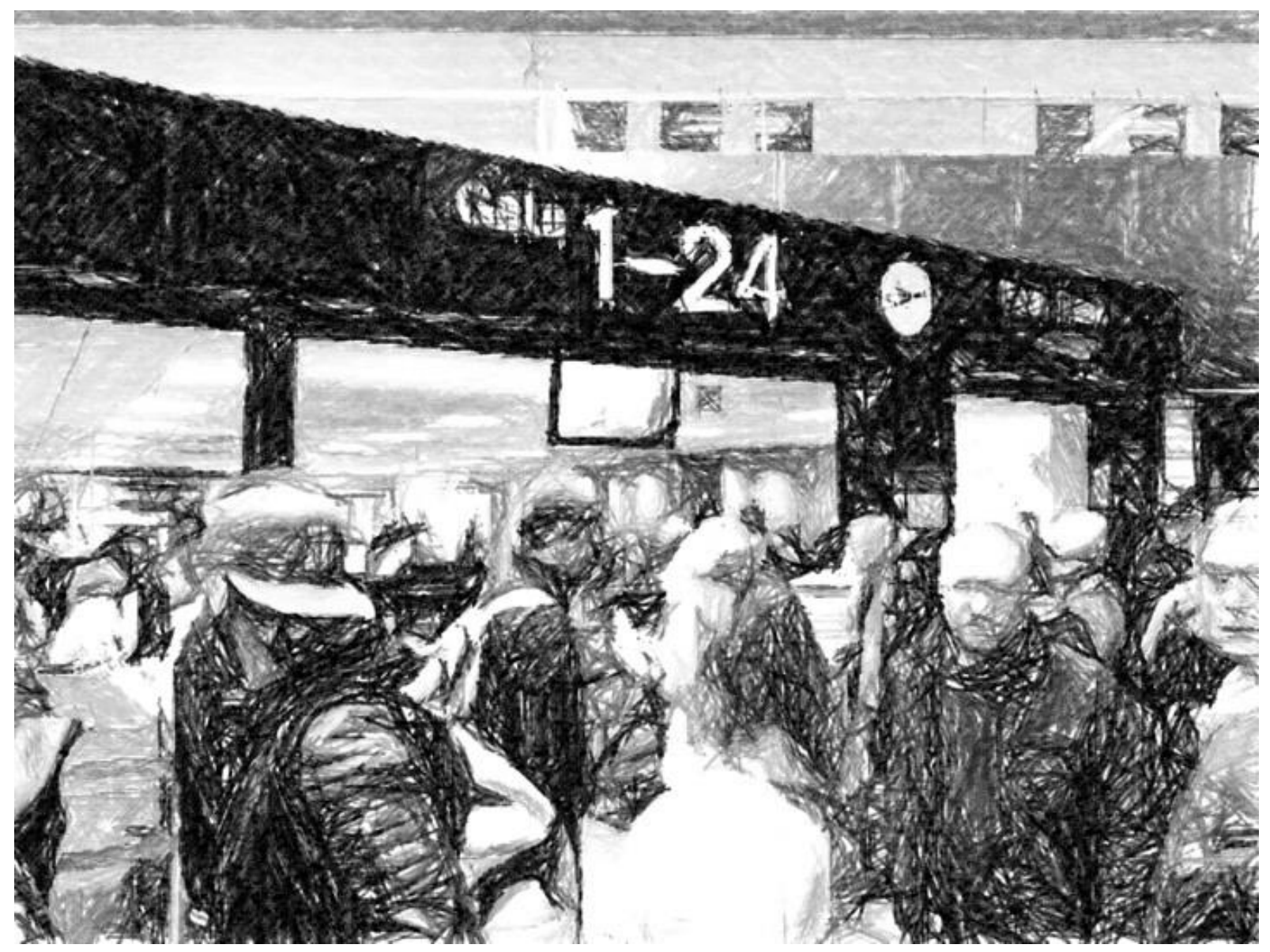

Figur 4. Säkerhetskontrollen, Arlanda Flygplats

Efter att ha passerat säkerhetskontrollens 'bundna' rum, dirigeras resenärens kropp till shoppingloungen (figur 5), ett öppet rum med rundade former, högt i tak och ljusa och starka 'konsumtionsfärger' samt en mångfald språkliga erbjudanden. I kontrast till föregående rum afforderar dessa resurser 'frihet' och 'energiboost' och bjuder in till ett slags 'obunden konsumtion'. 


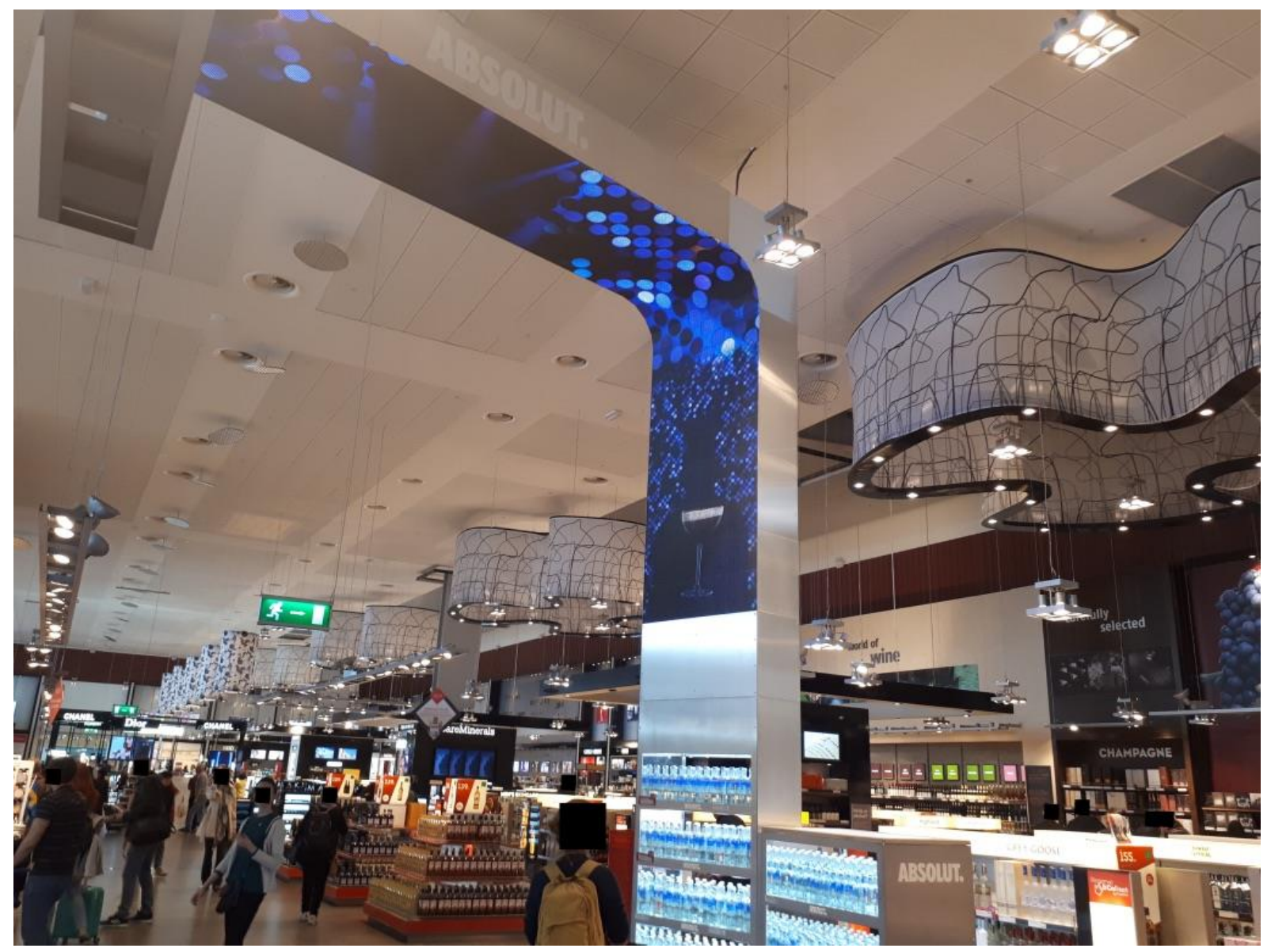

Figur 5. Shoppingloungen, Arlanda flygplats

Från shoppingloungen leds resenärerna slutligen till gateloungen. Där används resurser som låg takhöjd och mjuka golv (som dämpar ljus, ljud och rörelse) för att affordera "bunden avkoppling” samtidigt som glasväggar i gateloungen med utsikt mot flygplanen afforderar "obunden frihet" (figur 7). 

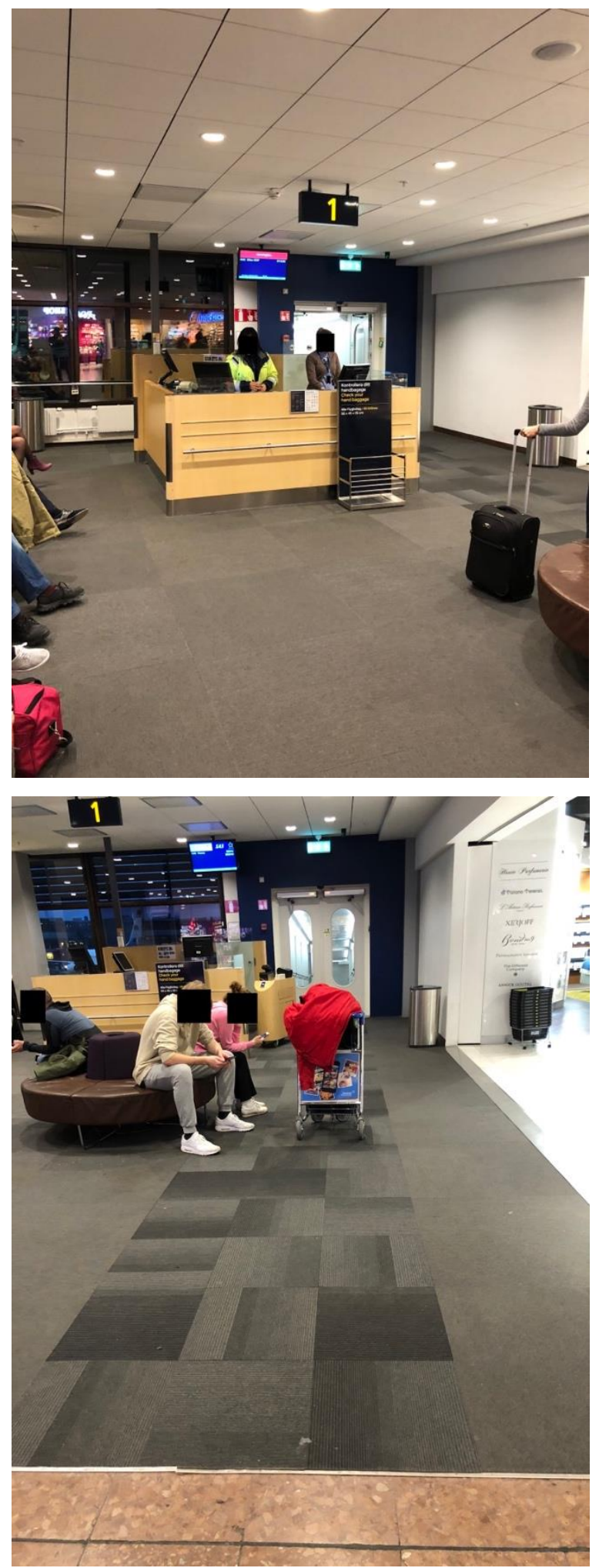

Figur 6. Gatelounge, Arlanda flygplats

Ledin, Nyström Höög, Tønnesson och Westberg 


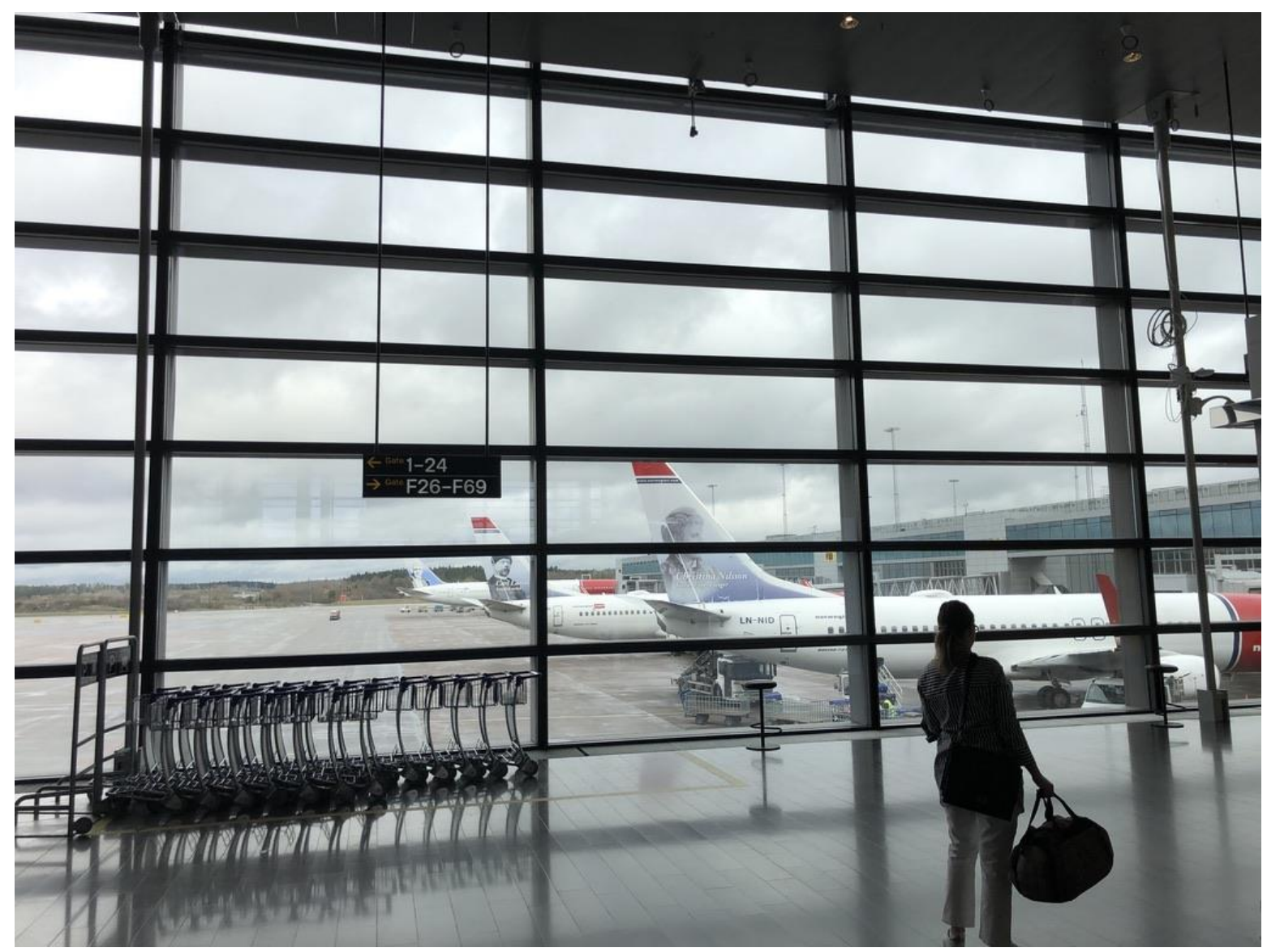

Figur 7. Glasväggar i gateloungen, Arlanda flygplats

Som figur 3-7 illustrerar kan vi alltså urskilja en spatial rytm (Lefebvre \& Régulier, 2004; McMurtrie, 2017) mellan flygplatsens olika delar, och kontrasten mellan rummens relativa slutenhet och öppenhet är handlingsdirigerande genom att den bjuder in till olika känslor och handlingar: öppna rum bjuder in till 'frihet' och 'energi', medan de slutna rummen afforderar 'kontroll', 'lugn' och 'trygghet' (jfr Stenglin, 2004). Flygplatsen delar alltså samma generiska funktion som andra typer av informativ och rådgivande sakprosa - att skapa känslor av lugn och kontroll i ett potentiellt kaotiskt läge.

Som både värdegrundstexterna och flygplatsen illustrerar innebär en betoning av funktion och multimodalitet att praktik sätts i den analytiska förgrunden, delvis i linje med Karlsson och Landqvists (2018) argumentation. Vi menar 
därför att sakprosabegreppets fortsatta relevans i många sammanhang ligger i förledet sak i kombination med kommunikativ funktion snarare än i efterledets prosa.

\section{Sakprosaforskningens framtid}

Den framtida sakprosaforskningen bör inte avkrävas ett fokus på texters multimodalitet. I varje enskilt forskningsprojekt måste forskningsfrågorna styra undersökningen, och i många fall kommer sakprosastudier, också när det finns ett starkt kontextuellt intresse, fortsätta att rikta uppmärksamheten mot skriftspråk. Så argumenterar exempelvis Hestbæk Andersen och van Leeuwen (2018) för att multimodalitetsforskare inte får glömma bort det viktiga kommunikativa arbete som skriftspråket har särskilda affordanser att utföra, även i texter som är uppenbart multimodala. Även om vi har argumenterat för att alla texter är multimodala, så finns det texter där multimodaliteten inte är relevant för forskningsfrågorna. Eller rättare sagt: även om texterna är multimodala, behöver inte forskningsfrågorna nödvändigtvis relevantgöra alla semiotiska resurser och affordanser som tas i bruk.

Inte minst gäller detta den litterära institutionens sakprosa (se dock Nørgaard, 2012 för multimodala ingångar till litterär stilistik) och myndigheters utredningsprosa, där bokstäver på papper eller skärm fortfarande utgör de mest centrala semiotiska resurserna. Det är en fortsatt legitim uppgift för sakprosaforskningen att undersöka textstruktur, retoriska appeller eller exempelvis användning av källor i kanonisk litterär sakprosa såsom Peter Englunds Poltava eller i globalt konstituerande texter såsom Brundtland-kommisionens Our Common Future.

Samtidigt menar vi att sakprosabegreppet blir alltför restriktivt om det avgränsas mot ickeverbala medier och modaliteter som tal, layout, teckningar, 
bilder, video, musik och arkitektur. Till och från är det underförstått att en multimodal analys är en visuell analys, men också det riskerar att bli för snävt. För sakprosaforskningen bör samspelet mellan verbalspråket och andra semiotiska resurser stå i centrum, oavsett om det handlar om myndighetskommunikation i form av film eller samverkan mellan verbalspråkig kommunikation och arkitektoniska resurser på t.ex. flygplatser och i shoppingcentrum eller i mer pedagogiska rum som museer eller klassrum. Ur detta perspektiv blir det, som vi ovan argumenterat för, motiverat och nödvändigt att ta fasta på affordanser - det vill säga inneboende möjligheter och begränsningar i olika semiotiska material. Avslutningsvis vill vi betona att det för sakprosaforskningen är relevant att undersöka sådana samspel synkront - hur olika semiotiska resurser samverkar i ett abstraherat, och fruset ögonblick - såväl som diakront - hur yttranden, texter och genrer ingår i sociala processer och praktiker. Men, som Bakhtin har lärt oss, bär varje yttrande på både förfluten tid, framtid och samtid i sig självt (Bakthin, 1986; Asdal m.fl., 2008). Så kanske är de allra bästa forskningsfrågorna i framtidens mer och mindre multimodalt inriktade sakprosaforskning historiska i denna radikala förståelse: alla texter är dynamiska och performativa: de hyser historia och skapar själva historia.

\section{Referenser}

Andersen, T. H. \& van Leeuwen, T. (2018) Hvorfor og hvordan 'betyder' nethandel? Om blandingen af teksttyper i Zalandos netbutik [Why and how does online shopping 'mean'? On the mixing of textual types in Zalando's web shops]. MedieKultur: Journal of media and communication research, 34(64). DOI: https://doi.org/10.7146/mediekultur.v34i64.25012 
Asdal, K. et. al. (2008). Tekst og historie. A lese tekster historisk. Oslo:

Universitetsforlaget.

Bakhtin, M.M. (1986). Speech Genres and Other Late Essays. Austin:

University of Texas.

Barthes, R. (1967) [1963]. Elements of semiology. London: Cape.

Bauldry, A. \& Thibault, P.J. (2006). Multimodal Transcription and Text Analysis: A Multimedia Toolkit and Coursebook. London/Oakville: Equinox.

Berge, K.L. (2001). Det vitenskapelige studiet av sakprosa. Om tekstvitenskapelige utfordringer og løsninger i norsk og svensk sakprosaforskning. I: Berge, K.L., Breivega, K.R., Roksvold, T. \& Tønnesson, J.T. red. Fire blikk på sakprosaen, s. 9-71. Oslo:

INL/ILN, Universitetet i Oslo: Prosjektmiljøet Norsk sakprosa.

Berge, K.L. (2002). Teksthistorie: Tekstvitenskapelige bidrag. I: Berge, K.L. (red.), Teksthistorie: tekstvitenskapelige bidrag, s. 5-20. Oslo: INL/ILN, Universitetet i Oslo: Prosjektmiljøet Norsk sakprosa.

Berge, K.L. \& Ledin, P. (2001). Perspektiv på genre. Rhetorica Scandinavia, 18 , s. $4-16$.

Bezemer, J. \& Jewitt, C (2009). Social Semiotics. I: Östman, J.O. \& Verschureren, J. red. Handbook of Pragmatics: 2009 Installment, s. 1-13. Amsterdam: John Benjamins.

Bhatia, V.K. (1993). Analysing genre: language use in professional settings. London: Longman 
Björkvall, A. (2009). Den visuella texten: multimodal analys i praktiken. Stockholm: Hallgren \& Fallgren.

Björkvall, A. (2018). Visuell textanalys. I: Boréus, K. \& Bergström, G. red. Textens mening och makt: Metodbok i samhällsvetenskaplig text- och diskursanalys, s. 355-399. Lund: Studentlitteratur AB.

Björkvall, A. \& Jacquet, E. (2014). Skrivande och textskapande med datorer i högstadiet: Ett ekologiskt perspektiv på möjligheter och utmaningar med "entill-en”-projekt. Viden om litteracy, 16, s. 18-27. Tillgänglig på: https://www.videnomlaesning.dk/media/1502/16 anders-bjorkvall ewajacquet.pdf

Björkvall, A., \& Nyström Höög, C. (2019). Legitimation of value practices, value texts, and core values at public authorities. Discourse \& Communication.

DOI: https://doi.org/10.1177/1750481319842457

Björkvall, A., Westberg, G., \& Van Meerbergen, S. (2019). Anslagstavlan: Vägvisare till det lokala lärandets semiotiska landskap?. I: Svenskans beskrivning 36: Förhandlingar vid trettiosjätte sammankomsten. Uppsala 25-27 oktober 2017, s. 37-52, utg. av Bianchi, M., Håkansson, D., Melander, B., Pfister, L., Westman, M. \& Östman, C. Uppsala: Uppsala universitet.

Blåsjö, M., Johansson, S. \& Jonsson, C. (2019). ”Put a meeting in my calendar!" The literacy practice of the digital calendar in workplaces, Sakprosa, 11(1). DOI: http://dx.doi.org/10.5617/sakprosa.5951

Bolter, Jay David (2001). Writing Space: Computers, Hypertext and the Remediation of Print. Mahwah, NJ: Lawrence Erlbaum Associates. 
Brinch Jørgensen, I. (2016). Når steder skapes: Fire studier av stedsutviklingens visuelle retorikk [Doktorsavhandling]. Universitetet i Oslo.

Butcher, S. H. (1902). The Poetics of Aristotele. London: MacMillan \& Co.

Byrman, G. (2001). Från kakaosmör till kondom. I: Melander \& Olsson (red.), Verklighetens texter. Sjutton fallstudier, s.339-383. Lund: Studentlitteratur.

Cortsen, R.P. (2016). Sagprosa i tegneserieform - en præsentation af informationstegneseriers status, værdi og didaktiske potentiale, Sakprosa, 8(2). DOI: $\underline{\text { http://dx.doi.org/10.5617/sakprosa.2700 }}$

Culler, J. (2001). The Pursuit of Signs: Semiotics, Literature, Deconstruction. New York: Routledge

Ekvall, U. (2001). Den styrda och styrande läroboken. I Melander \& Olsson (red.), Verklighetens texter. Sjutton fallstudier, s. 43-80. Lund:

Studentlitteratur.

Englund, B. \& Ledin, P. (2003). Teoretiska perspektiv på sakprosa. Lund: Studentlitteratur.

Fairclough, N. (1992). Discourse and social change. Cambridge: Polity Press.

Frandsen, F., Johansen, W. \& Ellerup Nielsen, A. (1997). International markedskommunikation i en postmoderne verden. Århus: Systime.

Frøjd, Y. (2018). "Global dannelse i møte med Operasjon Dagsverks testimonials" i "Hvem bryr seg?" Global solidaritet og skyld i Operasjon Dagsverks materiell [Doktorsavhandling]. Universitetet i Oslo, artikel 3. 
Gibson, J.J. (1977). The Theory of Affordances, I: Perceiving, Acting, and Knowing. Towards an Ecological Psychologi. Hillsdale, N.J.: Lawrence Erlbaum Associates. / Hoboken, NJ: John Wiley \& Sons Inc.

Grepstad, O. (1997). Det litterære skattkammer. Sakprosaens teori og retorikk. Oslo: Samlaget.

Halliday, M.A.K. (1978). Language as social semiotic: The social interpretation of language and meaning. London: Edward Arnold.

Halliday, M.A.K. (1985). An Introduction to Functional Grammar. London and Baltimore, Md.: Edward Arnold.

Hanghøj, T., Lieberoth \& A., Misfeldt, M. (2018). Can cooperative video games encourage social and motivational inclusion of at-risk students? British Journal of Educational Technology. 49(4), s. 775- 799. DOI:

https://doi.org/10.1111/bjet.12642

Hjelmslev, L. (1943). Omkring sprogteoriens grundlæggelse. København: Munksgaard.

Hodge, B. \& Kress, G. (1988). Social Semiotics. Cambridge: Polity Press.

I Tseng, C. (2013). Cohesion in film: tracking film elements. Houndmills, Basingstoke, Hampshire: Palgrave Macmillan.

Insulander, E. (2010). Tinget, Rummet, Besökaren: Om Meningsskapande På Museum [Doktorsavhandling]. Stockholms universitet. Tillgänglig på: http://urn.kb.se/resolve?urn=urn:nbn:se:su:diva-37403 (nedladdad 1 april 2019).

Ledin, Nyström Höög, Tønnesson och Westberg Sakprosa.no $42 / 50$ 
Jaworski, A. \& Thurlow, C. (2013). The (de-)centring spaces of airports:

Framing mobility and multilingualism. I: Pietikäinen, S. \& Kelly-Holmes. H. (red.), Multilingualism and the Periphery, s. 154-198. Oxford \& New York: Oxford University Press.

Jewitt, C. (2014). An introduction to multimodality. I C. Jewitt (red.), Routledge Handbook of Multimodal Analysis, s. 15-30. London: Routledge.

Jewitt, C., Bezemer, J. \& O’Halloran, K. (2016). Introducing Multimodality. Milton Park, Abingdon, Oxon: Routledge.

Johannesson, L. (1978). Den massproducerade bilden: ur bildindustrialismens historia. Stockholm: AWE/Geber.

Johnsen, E. B. \& Eriksen, T.B. (1998). Norsk litteraturhistorie. Sakprosa fra 1750 til 1995 red (to bind).

Juuhl, G.K. (2014). I det mykje skrivne. Ei undersøking av ungdoms digitale tekstar i skule og fritid som situerte, retoriske handlingar [Doktorsavhandling]. Universitetet i Oslo.

Karlsson, A. (2002). Skriftbruk i förändring: en semiotisk studie av den personliga hemsidan [Doktorsavhandling]. Stockholms universitet.

Karlsson, A. \& Landqvist, M. (2018). Gränsöverskridande meningsskapande: Om relevansen hos begrepp som text och sakprosa för förståelsen av hälsokommunikation. Sakprosa, 10(1). DOI: http://dx.doi.org/10.5617/sakprosa.5725

Kendon, A. (2004). Gesture. Cambridge University Press: Cambridge, U.K. 
Kjeldsen, J.E. (2002). Visuel retorik [Doktorsavhandling]. Universitetet i Bergen.

Knain, E. (2001). Naturfagets tause stemme. Diskursanalyse av lærebøker $i$ natur-og miljøfag. Oslo: INL/ILN, Universitetet i Oslo: Prosjektmiljøet Norsk sakprosa. Tillgänglig på:

https://www.hf.uio.no/iln/forskning/grupper/tekstretorikk/skriftserien/utgi velser/4Knain-Naturfagets-tause-stemme.pdf

Kress, G. (2003). Literacy in the New Media Age. London: Routledge.

Kress, G. (2009). Comments on Cope and Kalantzis. Pedagogies: An International Journal, 4(3), s. 205-212.

Kress, G. (2010). Multimodality: A Social Semiotic Approach to Contemporary Communication. London; New York: Routledge.

Kress, G. \& van Leeuwen, T. (1996). Reading Images: The grammar of visual design. 1. utg. London: Routledge.

Kress, G. \& van Leeuwen, T. (2001). Multimodal discourse: The Modes and Media of Contemporary Communication. London: Arnold.

Kress, G. \& van Leeuwen, T. (2006). Reading Images: The grammar of visual design. 2. utg. London: Routledge.

Kvåle, G. (2018). Kartlegging, kos og kontroll. En kritisk analyse av TRASskjemaet som multimodal tekst. Sakprosa, 10(2). DOI:

http://dx.doi.org/10.5617/sakprosa.5998 
Ledin, P. (1996). Genre: en forskningsöversikt. Rapporter från projektet svensk sakprosa, 2. Lund: Studentlitteratur. Tillgänglig på:

https://www.studentlitteratur.se/files/sites/svensksakprosa/Ledin_rappo2.p df

Ledin, P. (1998). ”Med det nyttiga skola wi söka förena det angenäma ...”. Text, bild och språklig stil i veckopressens föregångare. Rapporter från projektet Svensk sakprosa, 14. Lunds universitet.

Ledin, P. (2000). Veckopressens historia. II. Rapporter från projektet Svensk sakprosa, 29. Lunds universitet.

Ledin, P. (2015). Listans och tabellens semiotik. Sakprosa, 7(1). DOI: http://dx.doi.org/10.5617/sakprosa.947

Ledin, P. \& Machin, D. (2018a). Multimodal Critical Discourse Analysis. I: J. Flowerdew, J. \& Richardson, J.E. (red.), Routledge Handbook of Critical Discourse Studies, s.60-76. London: Routledge.

Ledin, P. \& Machin, D. (2018b). Doing visual analysis. From theory to practice. London: Sage.

Ledin, P. \& Machin, D. (2018c). Doing critical discourse analysis with multimodality: from metafunctions to materiality. Critical Discourse Studies, S. 1-18. DOI: $\underline{10.1080 / 17405904.2018 .1468789}$

Ledin, P. \& Machin, D. (2019). Final reply. Critical Discourse Studies, s. 1-9. DOI: https://doi.org/10.1080/17405904.2019.1614469 
Lefebvre, H. \& Régulier, C. (2004). The Rhythmanalytical Project. I:

Rhythmanalysis: Space, Time, and Everyday Life, s. 71-84. London; New York: Continuum.

Lind Palicki, L. (2010). Normaliserade föräldrar: en undersökning av Försäkringskassans broschyrer 1974-2007 [Doktorsavhandling]. Örebro universitet.

Løvland, A. M. (2007). På mange måtar: samensatte tekstar i skolen. Bergen: Fagbokforlaget. Løvland, A. M. (2014) Bilete av verkelegheit. Illustrasjonanes bidrag til framstilling av verkelegheit. Sakprosa, 6(3). DOI:

http://dx.doi.org/10.5617/sakprosa.102

Machin, D. (2004). Building the World's Visual Language: The Increasing Global Importance of Image Banks in Corporate Media. Visual Communication, 3(3), s. 316-336.

DOI: http://dx.doi.org/10.1177/1470357204045785

Machin, D. (2007). Introduction to Multimodal Analysis. London: Bloomsbury.

Machin, D. (2013). What is multimodal critical discourse studies? Critical Discourse Studies 10(4), s. 347-355. DOI:

https://doi.org/10.1080/17405904.2013.813770

Malmberg, B. (1973). Teckenlära. En introduktion till tecknens och symbolernas problematik. Stockholm: Aldus/Bonnier.

McMurtrie, R. J. (2017). The Semiotics of Movement in Space: A User's Perspective. New York: Routledge.

Ledin, Nyström Höög, Tønnesson och Westberg Sakprosa.no $46 / 50$ 
Melander, B. \& Olsson, B. (red.) (2001). Verklighetens texter. Sjutton fallstudier. Lund: Studentlitteratur

Michelsen, M. (2010). ”Her er det veldig mye informasjon”. Sakprosa, 2(1). DOI: http://dx.doi.org/10.5617/sakprosa.102

NLG, The New London Group (1996). A Pedagogy of Multiliteracies:

Designing Social Futures. Harvard Educational Review, 66 (1), s. 60-93. doi:10.17763/haer.66.1.17370n67v22j16ou.

Norris, S. (2004). Analyzing Multimodal Interaction: a methodological framework. New York: Routledge.

Nyström Höög, C. (2015). Värdegrundstexter - ett nytt slags uppdrag för klarspråksarbetet? Sakprosa, 7(2), s. 1-16. DOI:

http://dx.doi.org/10.5617/sakprosa.831

Nyström Höög, C. \& Björkvall, A. (2018). Keeping the discussion among civil servants alive: 'Platform of values' as an emerging genre within the public sector in Sweden, Scandinavian Journal of Public Administration, 22(3), s. $17-38$.

Nørgaard (2012). Multimodal stilistik. In: Andersen, T.H. and Boeriis, M. (red.), Nordisk Socialsemiotik: Pædagogiske, Multimodale Og Sprogvidenskabelige Landvindinger, s. 111-130. University Press of Southern Denmark studies in linguistics v. 22. Odense: Syddansk Universitetsforlag.

O'Halloran, K.L. (2008). Systemic functional-multimodal discourse analysis (SF-MDA): Constructing ideational meaning using language and visual imagery. Visual Communication 7(4), s. 443-475. DOI:

https://doi.org/10.1177/1470357208096210

Ledin, Nyström Höög, Tønnesson och Westberg Sakprosa.no $47 / 50$ 
O’Toole, M. (1994). The language of displayed art. London: Leicester University Press.

Pettersson, G. (2000). Från ord till bilder? En studie av samspelet mellan text och bild i uppslagsböcker under 1900-talet. Rapporter från projektet Svensk sakprosa, 30. Lunds universitet.

Peirce, C.S. (1931). Collected Papers. Cambridge, Mass.: Harvard University Press.

Pipping, R. (1938). Språk och stil. Finsk tidskrift 10, s. 267-276.

Ravelli, L.J. \& McMurtrie, R.J. (2015). Multimodality in the Built environment: Spatial Discourse Analysis. New York: Routledge. https://doi.org/10.4324/9781315880037.

Saussure, F.D. (1970 [1914]). Kurs i allmän lingvistik. Staffanstorp: Cavefors.

Sonesson, G. (2011). Bildens yta och djup. Grunder för en bildsemiotik. Signs - Scandinavian Section, 1, s. 115-162.

Seiler Brylla, C., Westberg, G. \& Wojahn, D. (2018). C som i kritik: Kritiska perspektiv inom text- och diskursstudier. I: Wojahn, D., Seiler Brylla, C. \& Westberg G. (red.), Kritiska Text- Och Diskursstudier. Södertörn Discourse Studies, s. 9-36. Huddinge: Södertörns högskola. Tillgänglig på: http://sh.diva-portal.org/smash/get/diva2:1190976/FULLTEXTo2.pdf (nedladdad 11 oktober 2018).

Spitzmüller, J. \& Warnke, I.H. (2011). Discourse as a 'linguistic object': methodical and methodological delimitations. Critical Discourse Studies, 8(2), s. 75-94. DOI: https://doi.org/10.1080/17405904.2011.558680 
Stenglin, M. K. (2004). Packaging curiosities: towards a grammar of threedimensional space. Sidney: [Doktorsavhandling]. University of Sydney.

Svensson, J. (2001). Fattigvårdsfrågan som diskursordning. I: Melander \& Olsson (red.), Verklighetens texter. Sjutton fallstudier, s. 401-442. Lund: Studentlitteratur.

Swales, J. (1990). Genre analysis: English in academic and research settings. Cambridge: Cambridge University Press.

Tønnesson, J. (2006). Alle tekster er sammensatte. Norsklæreren, 4 (30), s. $9-15$.

Tønnesson, T. (2008 og 2012). Hva er sakprosa. Utg. 1 og 2. Oslo: Universitetsforlaget.

Tønnesson (2019) (under utgivning). "Har kreativitet noen plass i stilarten 'sakprosa'? Rolf Pippings utløsning fra 1938 revisited". I: Brinch Jørgensen, I. \& Norunn Askeland, N. (red.), Kreativ akademisk skriving. Oslo: Universitetsforlaget (under utgivning).

Ulbæk, I. (2016). Dilemma-argumentation i radioprogrammet Mads og monopolet, Sakprosa, 8(2). DOI: http://dx.doi.org/10.5617/sakprosa.2884

van Leeuwen, T. (1999). Speech, music, sound. Basingstoke: Macmillan.

van Leeuwen, T. (2005). Introducing social semiotics. London: Routledge

Veum, A. (2008). Avisas andlet: førstesida som tekst og diskurs: Dagbladet 1925-1995. Oslo: [Doktorsavhandling]. Universitetet i Oslo. 
Veum, A. (2010). Historisk blikk på avisa som tekst og diskurs. Sakprosa, 2(1). DOI: http://dx.doi.org/10.5617/sakprosa.47

Voloshinov, V.N. (1986 [1929]). Marxism and the philosophy of language. Cambridge, Mass.: Harvard University Press.

Wagner, K. (2015). Reading packages: social semiotics on the shelf. Visual Communication, 14(2), s. 193-220.

Westberg, G. (2016). Legitimerade föräldraskap 1870-2010: En diskurshistorisk undersökning [Doktorsavhandling]. Stockholms universitet. Tillgänglig på:

http://sh.divaportal.org/smash/record.jsf?pid=diva2\%3A1184183\&dswid=69 $\underline{6}$

Westberg, G. (2017). Det legitima moderskapets genealogi: en transtextuell diskurshistorisk analys. Sakprosa, 9 (1). DOI:

http://dx.doi.org/10.5617/sakprosa.4083

Westberg, G. \& Björkvall, A. (2019). Representation som möjlighet: att ta steget bortom kritisk beskrivning. I: Insulander, E., Lindstrand, F., \& Selander, S. (red.), Design för lärande - Historia: Medeltiden som exempel, s. 161-176. Lund: Studentlitteratur.

Øierud, G. L. (2013). Gudstjenesters kommunikasjon og modelldeltakere. Tilrettelagt meningsskaping og resepsjonsvilkår i ulike gudstjenester [Doktorsavhandling]. Universitetet i Oslo. 